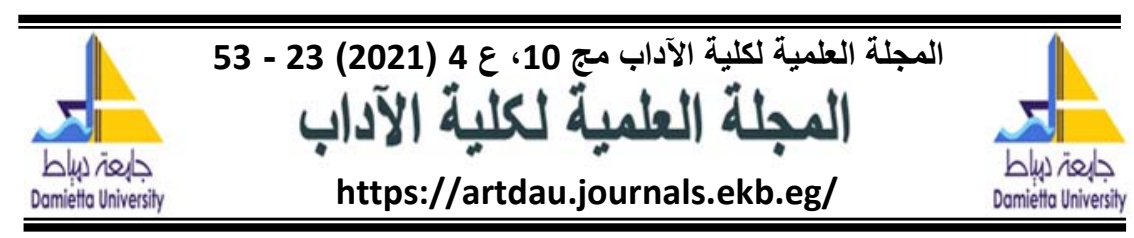

\title{
دور الجامعة فى تطوير البحث العلمي: دراسة ميدانية بجامعة دمياط
}

ياسمين إبراهيم أحمد أبو عبد الله طالبة ماجستير - قسم الاجنماع - كلية الآداب - جامعة دمياط. المستخلص الابد

البحث العلمي له أهمية جوهرية تتمثل في دراسة ظواهر المجتمع دراسة

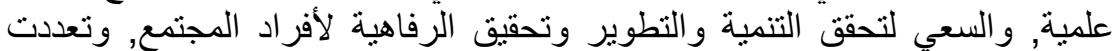

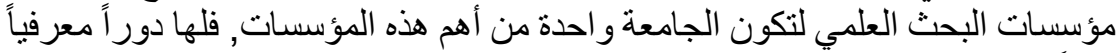

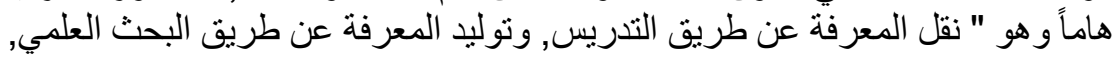

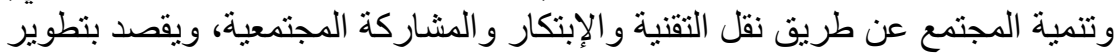

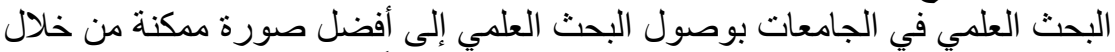

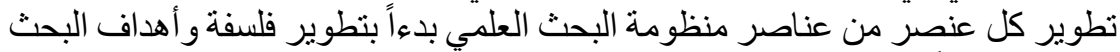

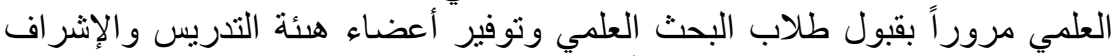

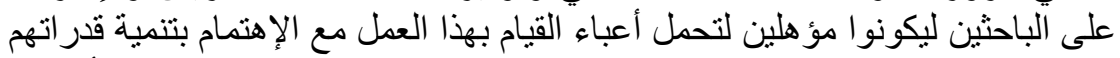

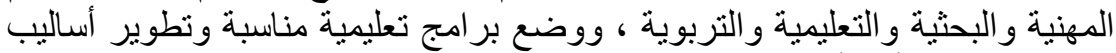

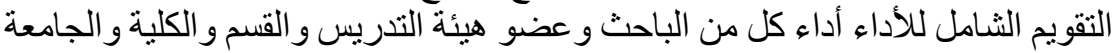

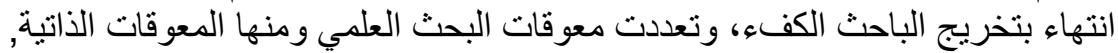

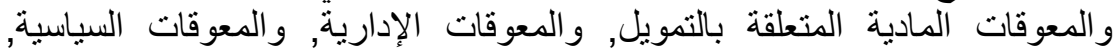

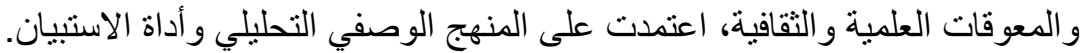

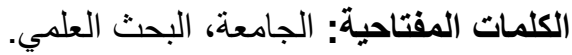

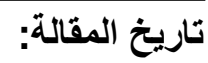

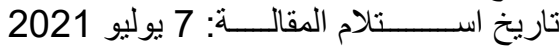
تاريخ استلام النسخة النهائية: 28 يوليو 2021 تاليو 2021 تاريخ قبـــــــل الدقالــــــــة: 9 أغسطس 2021 


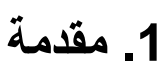

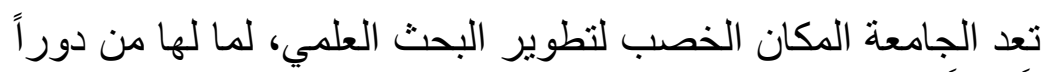

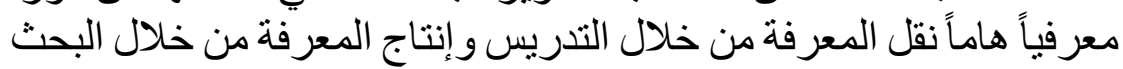

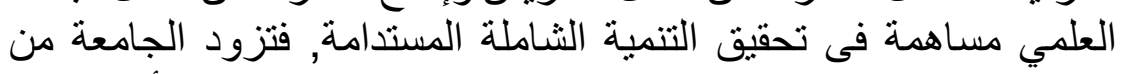

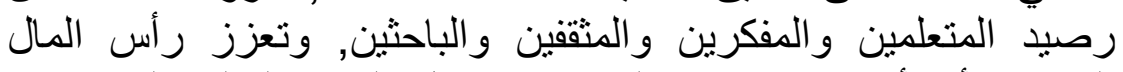

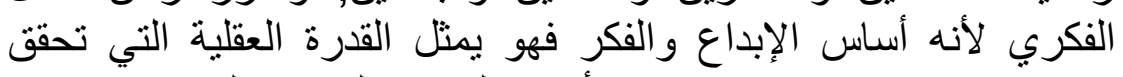

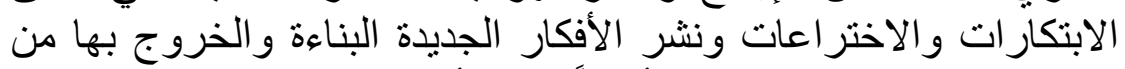

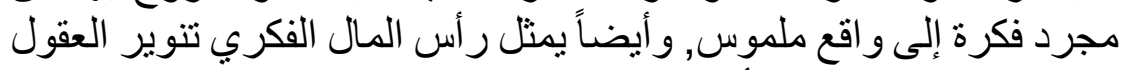
البشرية ورفع مكانتهم لأنهم ثروات الثرات المجتمع التي تحقق التنمية والابتكار

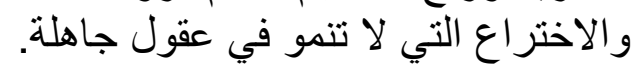

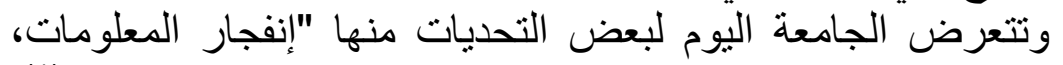

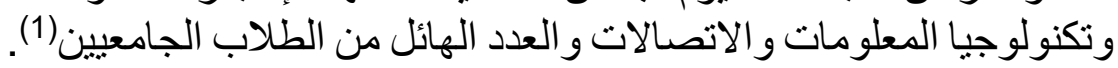

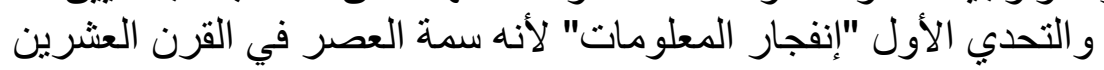

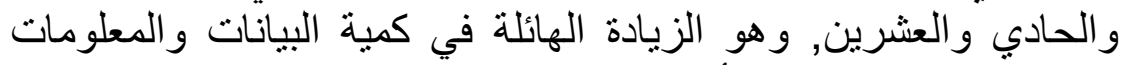

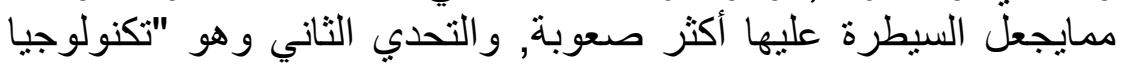

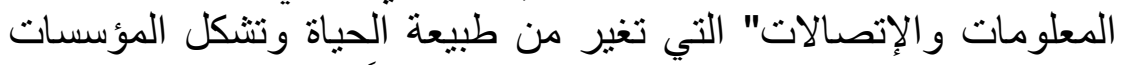

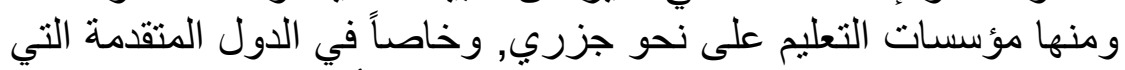

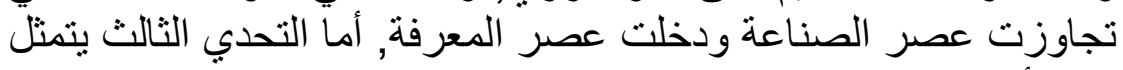
في الأعداد الهائلة من الطلاب المقبليين على التعليم العالي بصورة تلفئ التهوق قدرة الجامعات على إستعابها. ويعد البحث العلمي من المهام الرئيسية للجامعة بداية من البحوث

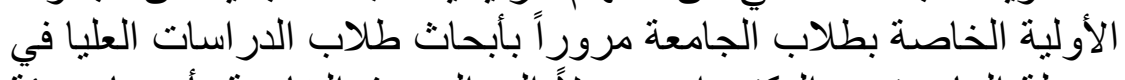

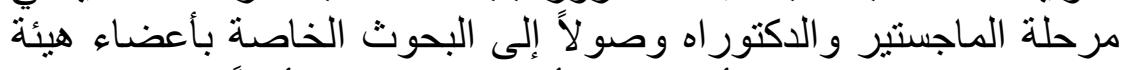

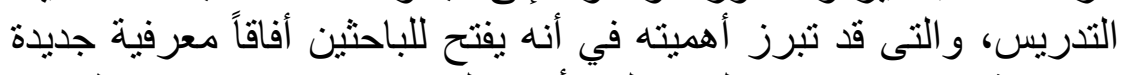

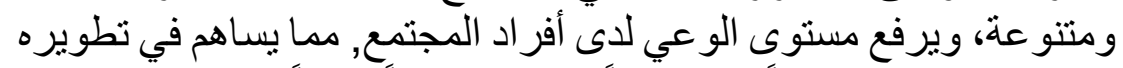

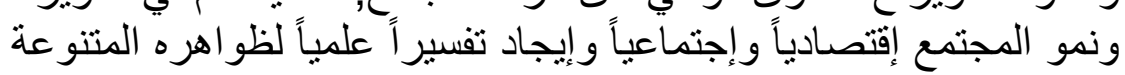

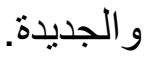

وسعت العديد من الجامعات إلى إيجاد جهات تتظيمية تتولى إدارة

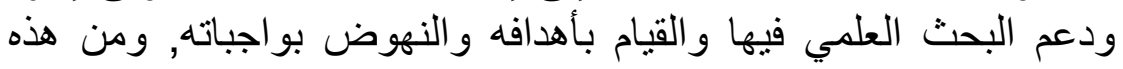

(1)محمد نبيل نوفل: الجامعة والمجتمع في القرن الحادي والعشرين, المجلة العربية لللتمية, المنظمة العربية للتربية و الثقافة و العلوم إدارة التنربية, مج 22, ع 1, 2002,

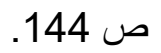

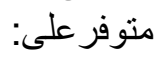
https://search.mandumah.com/Record/22341 (تم الوصول في: 13-619-619). 
الجهات الكراسي العلمية والتي تعتبر من أهم الجهات الداعمة والمنظمة

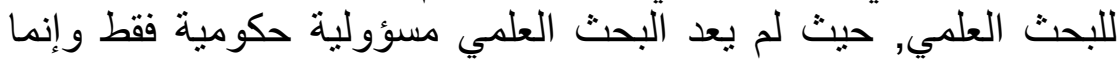

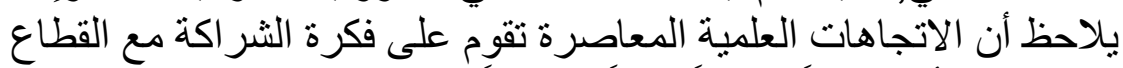

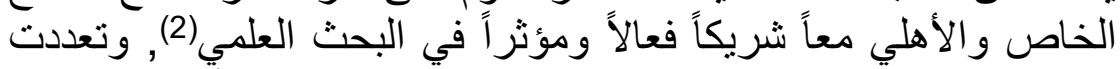

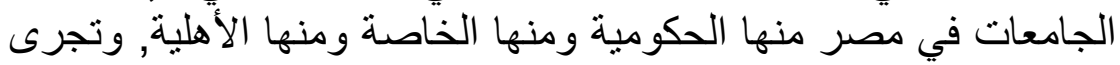

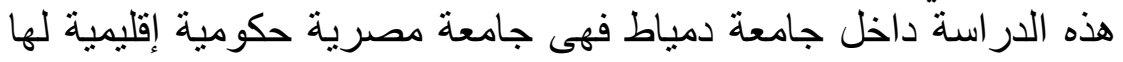

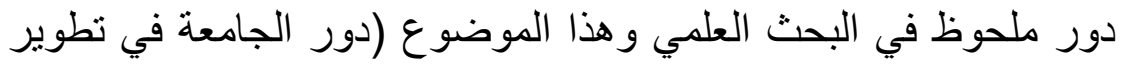

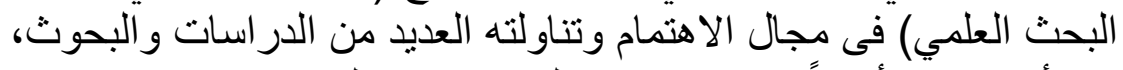
Sما أنه يندرج أيضاً فى تخصى الخص علم الاجتماع التربوى

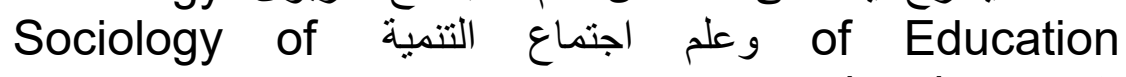
development 2. مشكلة الدراسة البة

البحث العلمي عبارة عن أسلوب تفكير وجهد يهدف إلى الى تحديد المشكلة

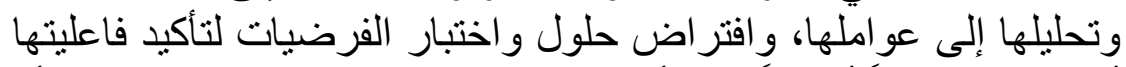

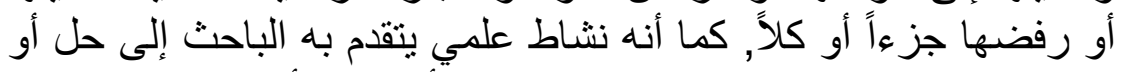

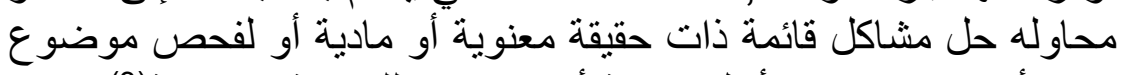

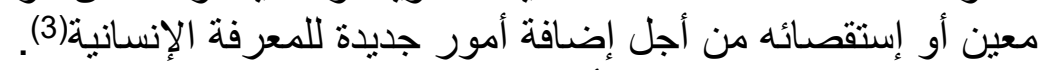

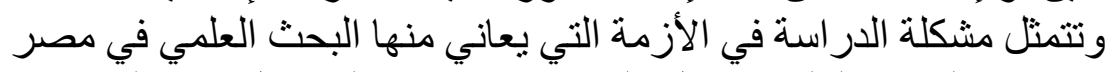

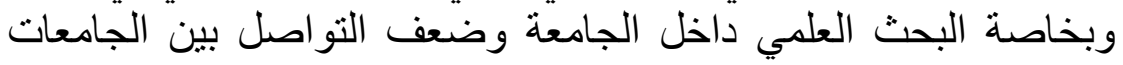

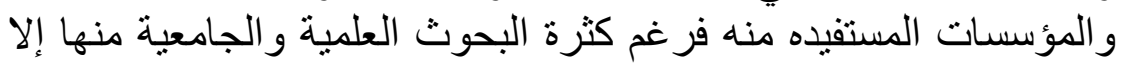

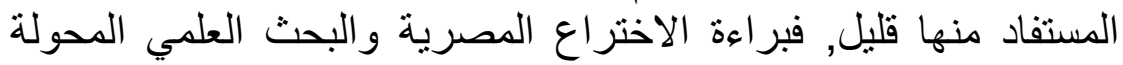

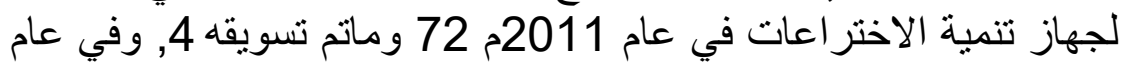

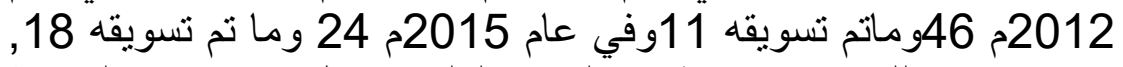

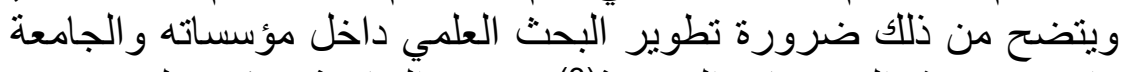

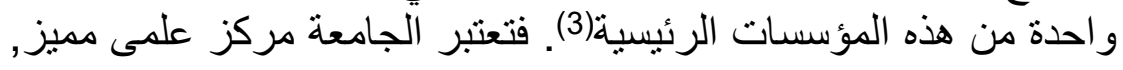

(1) خالد عبد الرحمن ياسين و أخرون: الكراسي العلمية ودور ها في تتمبة البحث العلمي

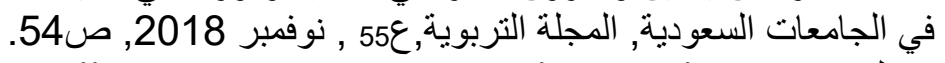

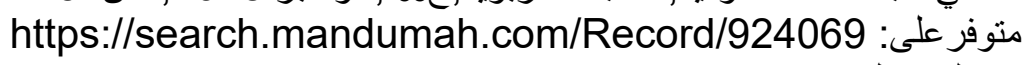
(تم الوصول في: 2021-2-27). (2)(يوسف خليل مطر: مناهج البحث العلمي, دار الكتب العلمية, بيروت, 2014,

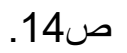
(3)الجهاز المركزي للتعبئة العامة والإحصاء: مصر في أرقام 2018, مطبعة الجهاز المركزي للتعبئة العامة والإحصاءة القاهة والإهاء 
يهدف إلى تتمية المجتمع علمياً وثقافياً و إقتصادياً كما تشكل الأداة الفعالة

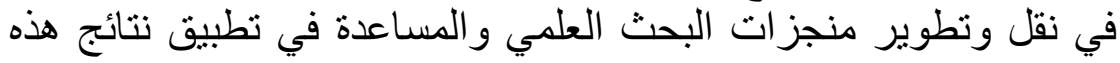

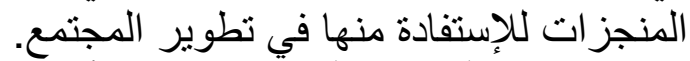
وتتبلور مشكلة الدراسة في التساؤل فئل الأتي:

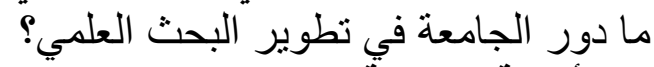
3. أهمية الدراسة الهية تبرز أهمية الدراسة في جانبين:

1.3 الأهمية النظرية النية

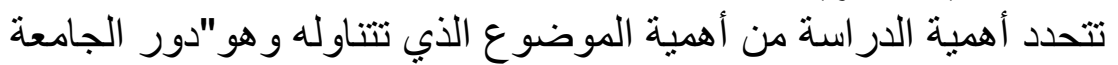

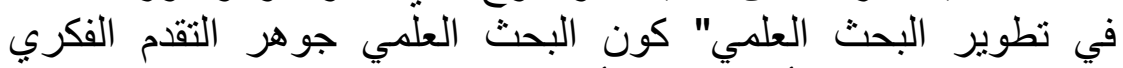

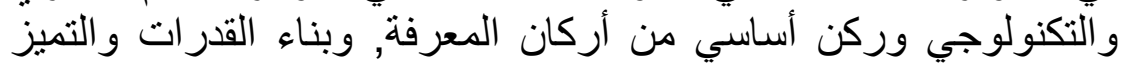

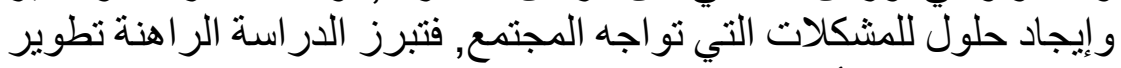

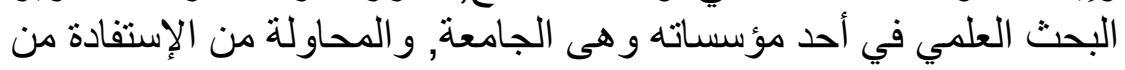

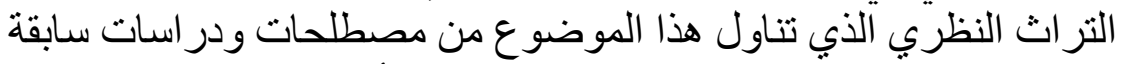

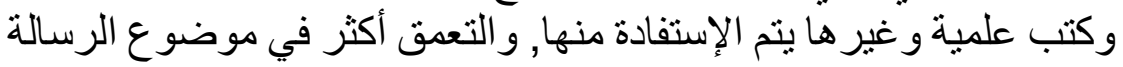

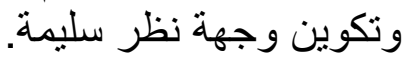

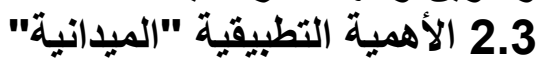

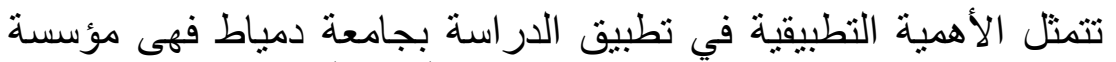

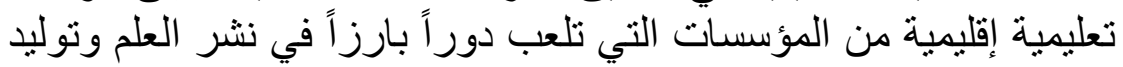

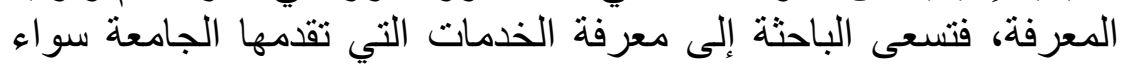

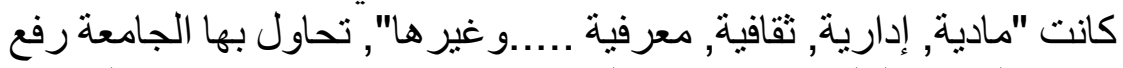

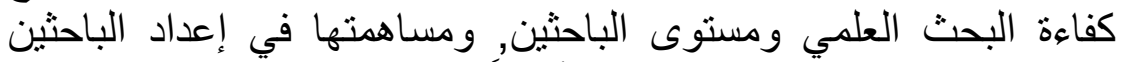

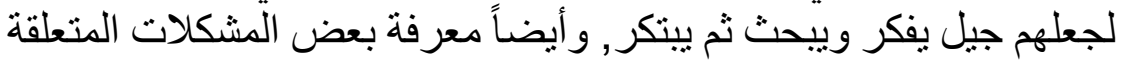

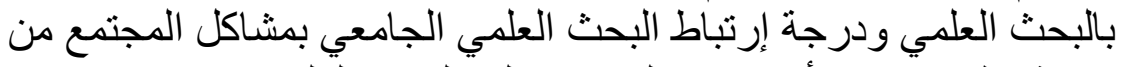
وجهة نظر بعض الأكاديمبين القائمين على البحثي البه العلمي.

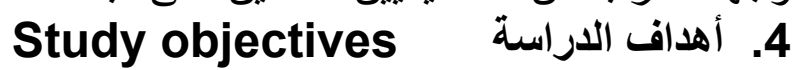
1. معرفة وظائف الجامعة الحالية وأهداف البحث العلمي الذي

$$
\text { يجري خلالها. }
$$

2. الوقوف على الأسس العلمية التي تعتمد عليها الجامعة لتطوير

$$
\text { البحث العلمي. }
$$

3. الكثف عن معوقات البحث العلمي الجامعي.

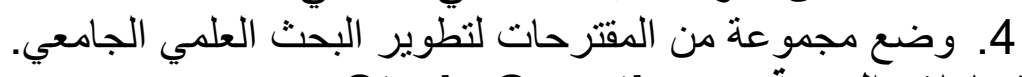

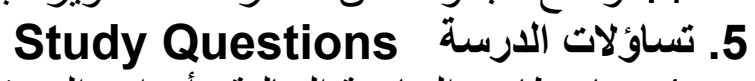

1. ما وظائف الجامعة الحالية وأهداف البحث العلمي الذي يجري

خلالها. 
2. ما الأسس العلمية التي تعتمد عليها الجامعة لتطوير البحث

العلمي.

3. ما معوقات البحث العلمي الجامعي.

6. 3. ما مقترحات تطوير البحثث العلمي الجامعي.

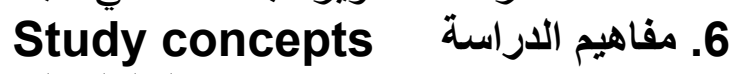

1.6 الدورفي :هe Role هو نمط السلوك الذي تنتظره الجماعة وتطلبه

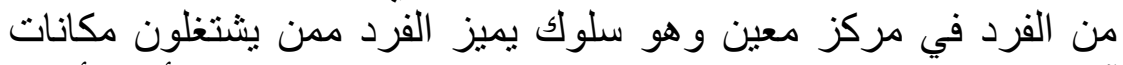

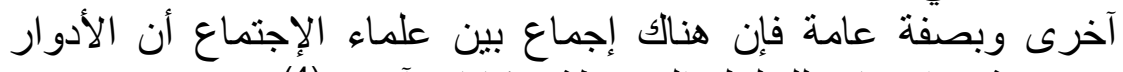

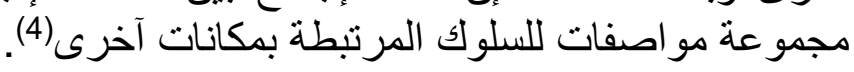

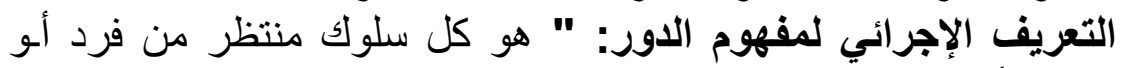

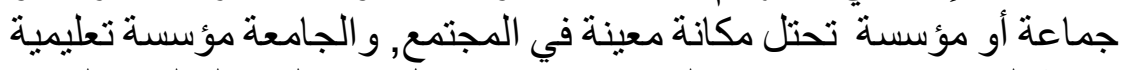

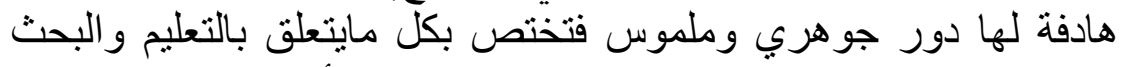

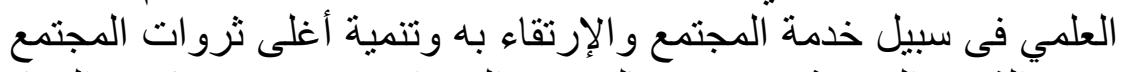

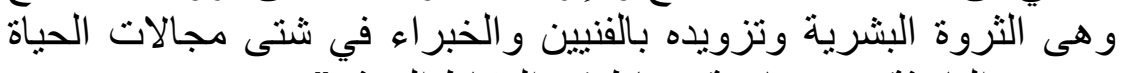
وتدرس الباحثة دور جامعة دمياط في النشاط البحثي".

2.6

University

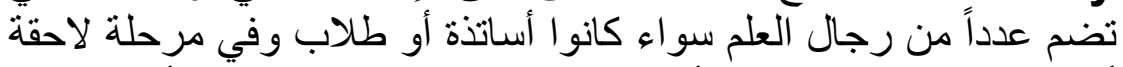

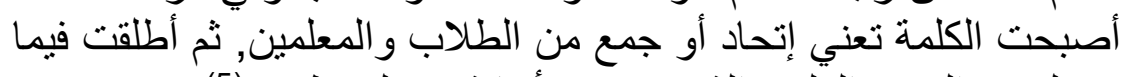

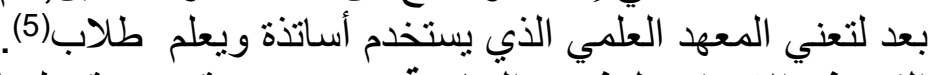

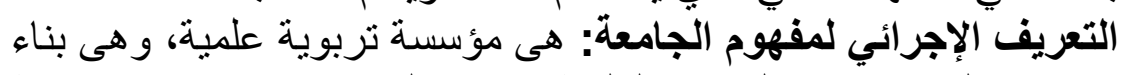

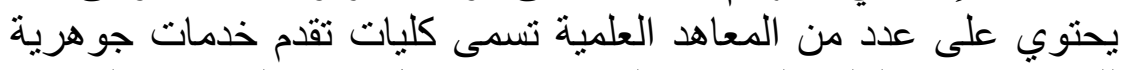

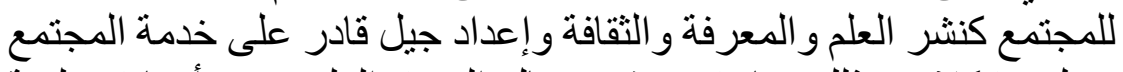

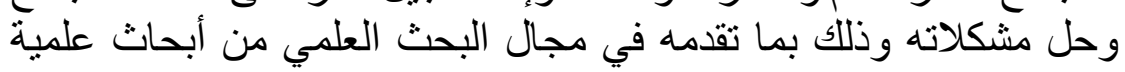

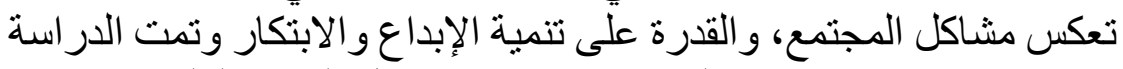

في جامعة دمياط كمؤسسة لها دور مؤثر في مجال البحت البحث العلمي".

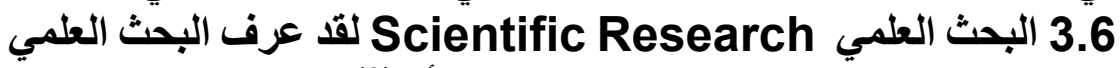
عدد من الكتاب وألخبراء المتخصصين على أنه(6):

(1)نصيف فهي منقريوس: النظريات العلمية والنماذج المهنية بين البناء النظري

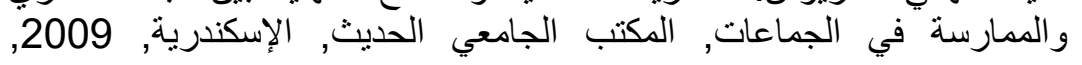

ص278.

(2)طه محمود: قضايا في التعليم العالي والجامعي، مكتبة النهضة المصرية،القاهرة،

r... A

(1)أحمد داوود الأشعري: الوجيز في طرق البحث العلمي، دار خوارزم العلمية،جدة ،

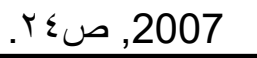


"طريقة من طرق التفكير الهنظم أو الدر اسة الدقيقة التى تعتمد على وسائل

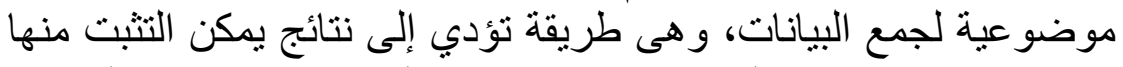
, كما يمكن تعميمها والخروج منها بقو العد علمية تلمية تسمح بتغيير الظاهرة موضوع الدر اسة, وتتيح إمكانية التتبؤ".

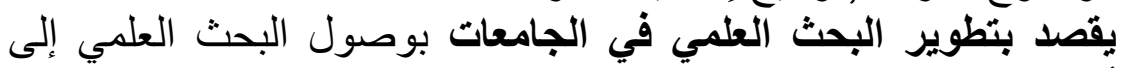

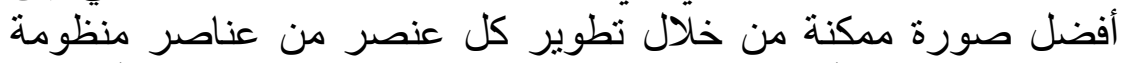

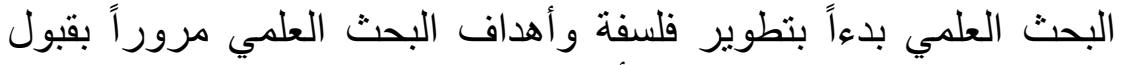

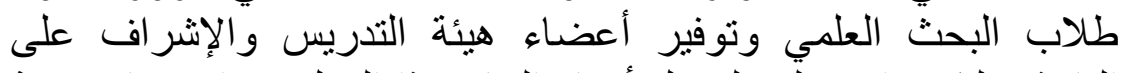

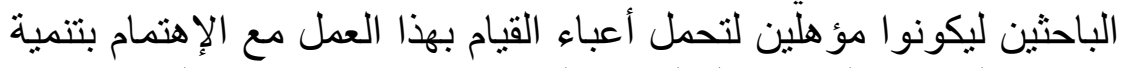

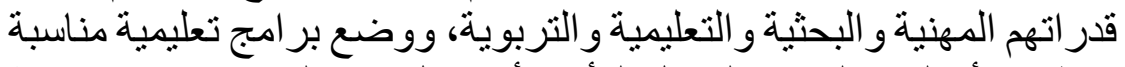

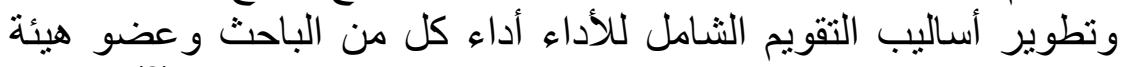

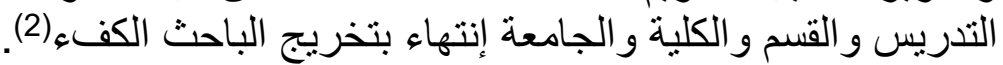

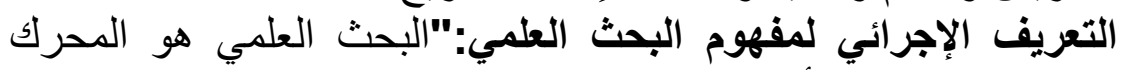

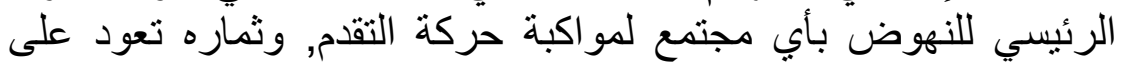

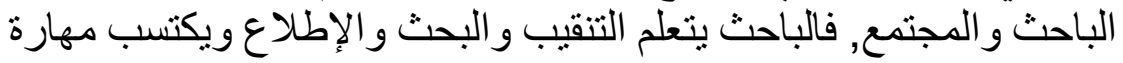

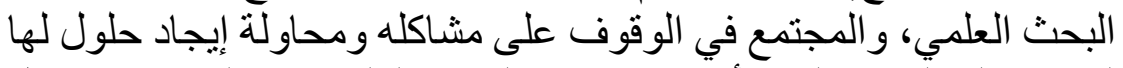

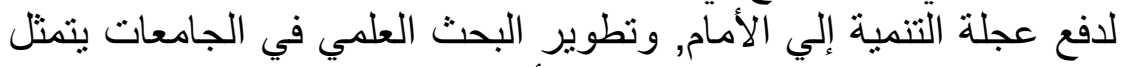

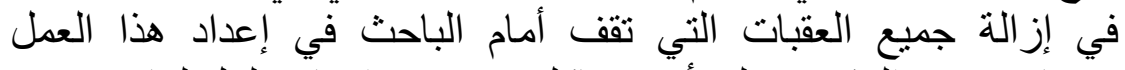
و ومساعدته في الّوقوف على أهم مشاكل مجتمعه و إيجاد حلول لهال لها".

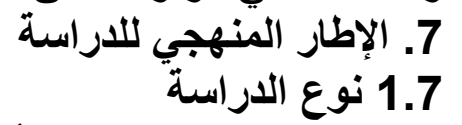

يمكن تحديد نوع الدراسة بأنها دراسة وصفية تحليلية وقد عرفها هويتنى

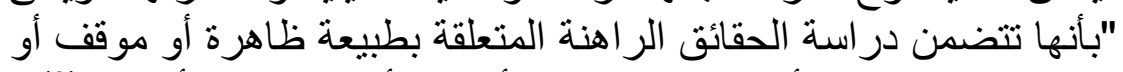

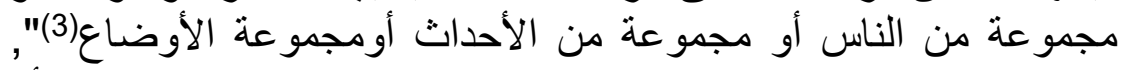

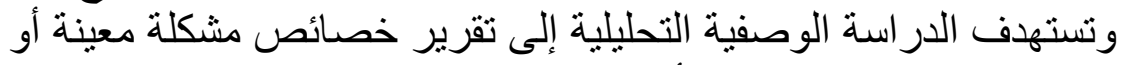

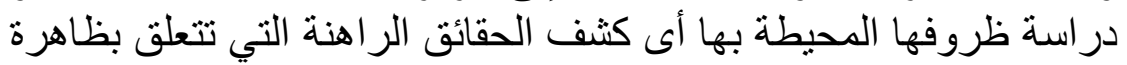
أو موقف أو مجمو عة من الأفر اد مع تسجيل دلالتها وخصائَسها لتها وتصنيفها

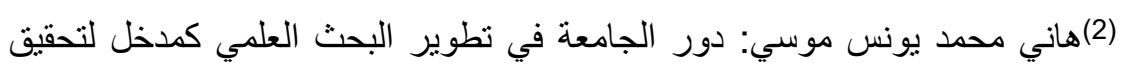

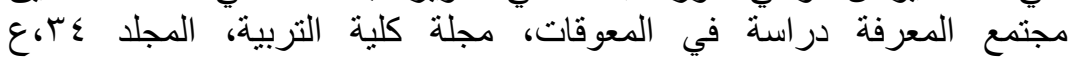

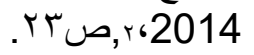
(3)محد سيد فهمي وآخرون: البحث العلمي و المتغيرات المعاصرة، دار الوفاء

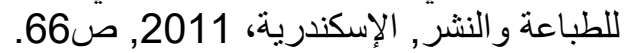


وكثف إرتباطه بمتغير ات أخرى بهذف وصف هذه الظاهرة وصفاً دقيقاً شاملاً من كافة جو انبها ولفت النظيرات اخرى إلى أبعاده المختلفة(7).

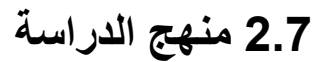

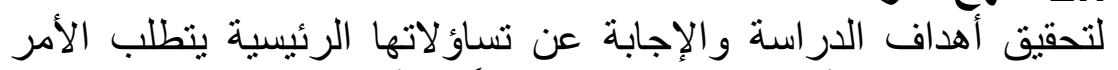

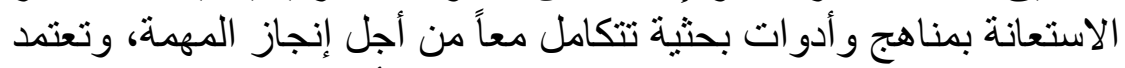

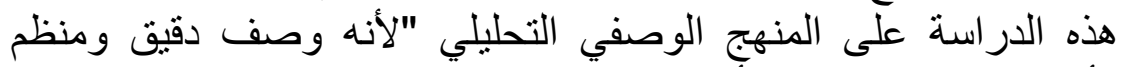

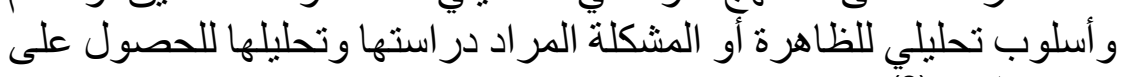
نتائج علمية"'(2).

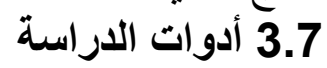
أداة الاستبيان: - أدوات

ويعد الاستبيان Questionnaire طريقة من طرق جمع المعلومات

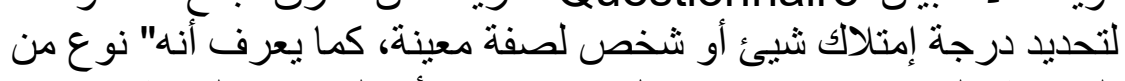

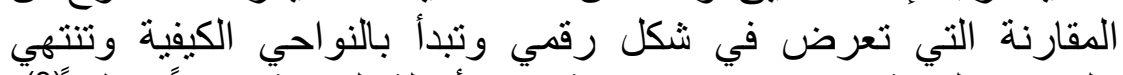

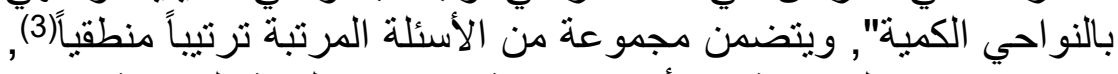

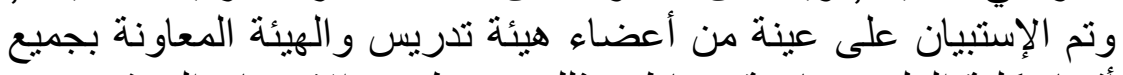

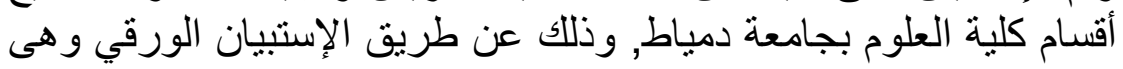

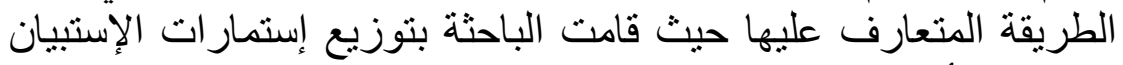

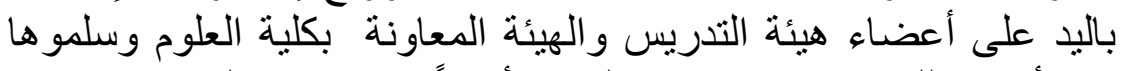

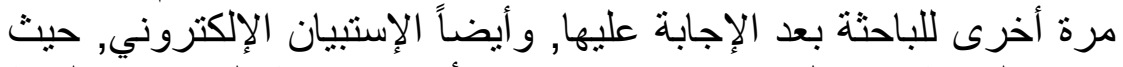

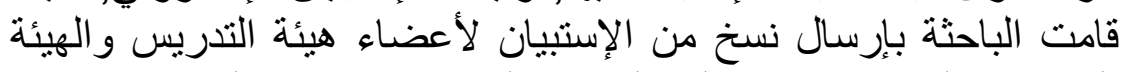

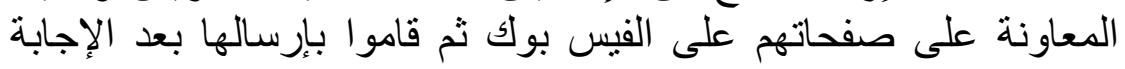
عليها.

\section{7 جمهور البحث}

جمهور البحث في هذه الدراسة عبارة عن عينة عمدية من أعضاء هيئة

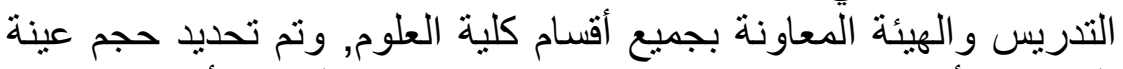
الدراسة بأنها (123) مفردة, وإستخدمت معهم الإنة الباحثنة أداة الإستنبيان

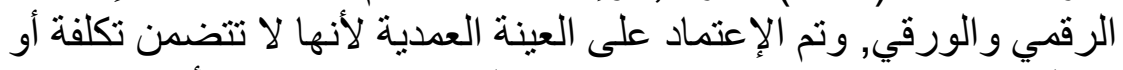

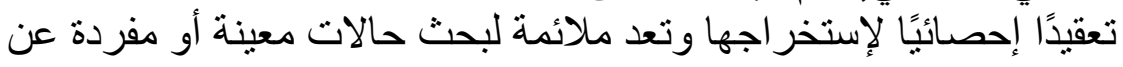

(1)محمد شفيق: البحث العلمي- المبادئ- الإعداد، المكتب الجامعي الحديث،

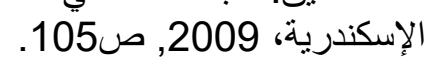

(2)Bill Gillham: developing a questionnaire, Continuum international publishing, Group, London,2007, p.

(3) عبد الله محمد عبد الرحمن: مناهج وطرق البحث الاجتماعي، مطبعة البحيرة،

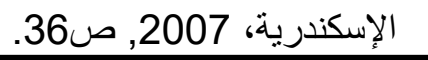




\section{7 مجالات الاراسة. تنقسم الدر اسة إلى ثناث الأن مجالات:}

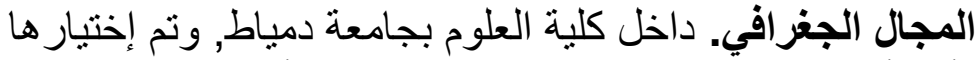

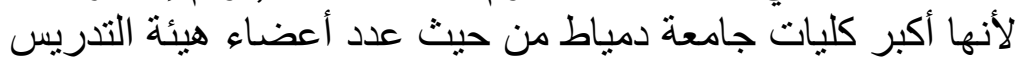
و الهيئة المعاونة وتتنوع الدراسة فيها فمنها النظرية و الميدانية هينة و العملية. المجال الزمني: النطاق الزمني الذي إستغرقته الدر اسة إستمر عامين تقريباً المجال البشري: تمت إجراءات الدراسة الميدانية على عينة عمدية

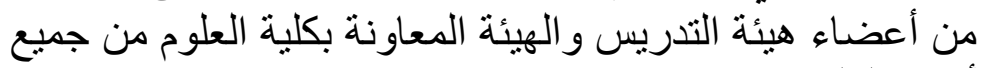
أقسام الكلية. 6.7 أسلوب التحليل والتفسير

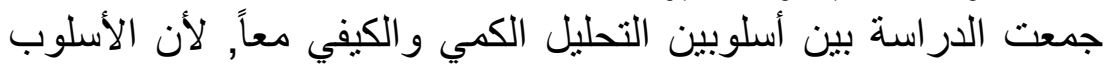

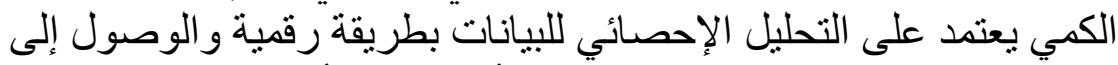

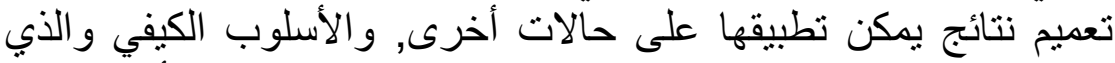

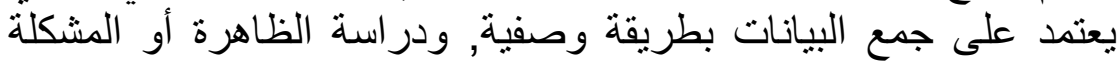

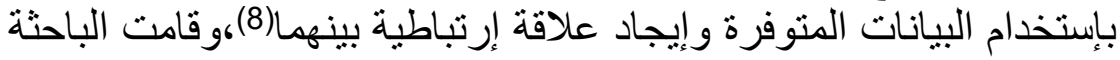

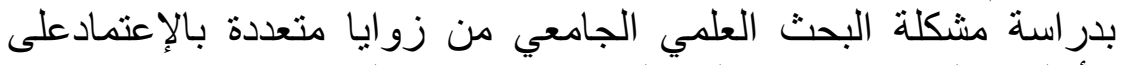

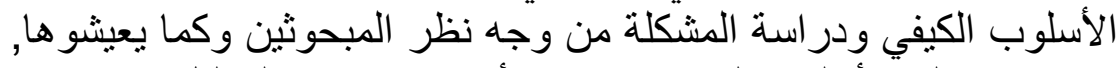

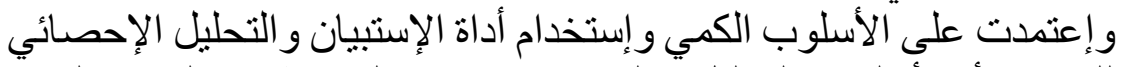

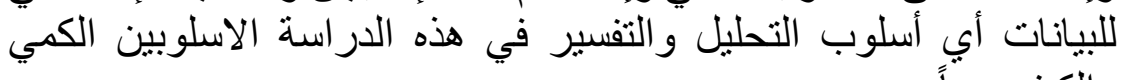
و الكيفي معاً. 8. أهم القضايا التي يتبناها البحث.

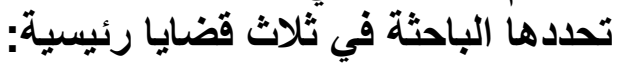

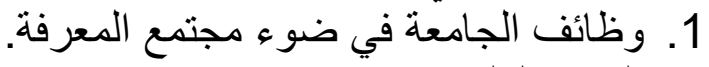

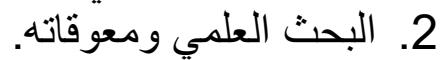
3. دور الجامعة في تطوير البحث العلمي ودئ وتثمية المجتمع 1.8 1. 1.8 وظائف الجامعة الحاليةً أولاً: نشر المعرفة المامعة

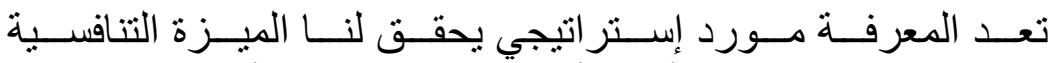

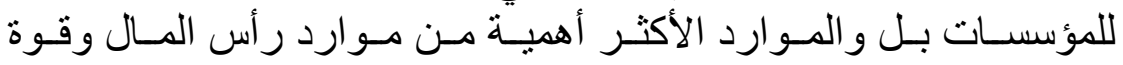

(1) فاتن عبد الحميد: أساسيات ومهار ات البحث التربوي والإجرائي، دار المجد للنشر

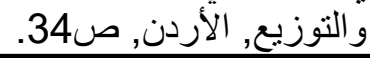




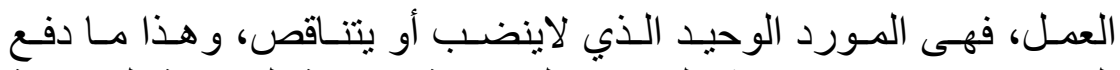

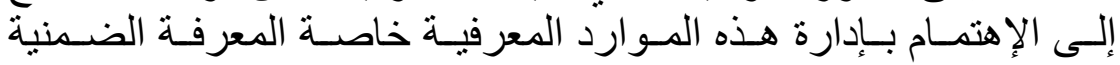

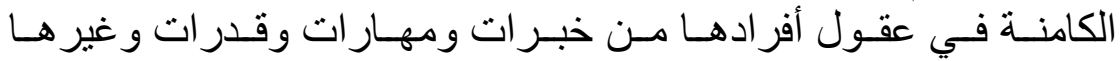
التي تقود إلىى الإبداع(9).

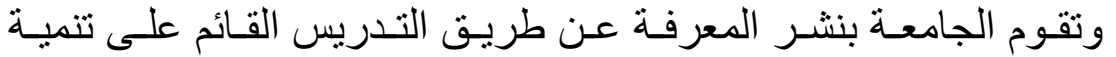

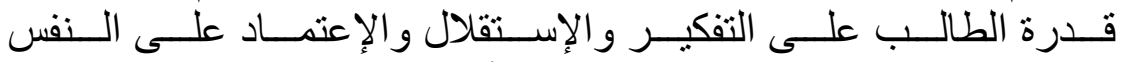

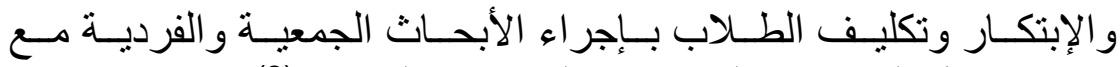

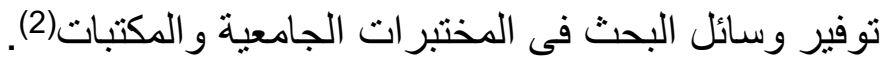

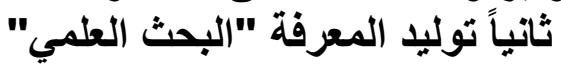

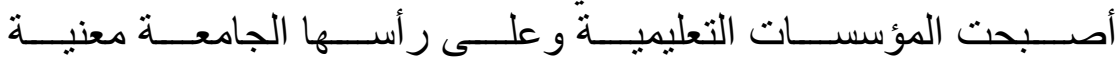

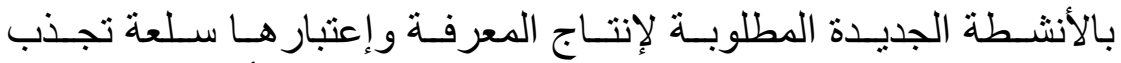

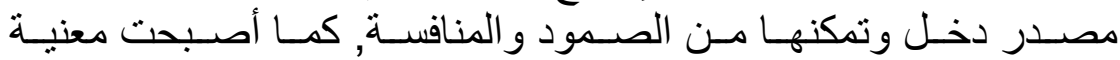

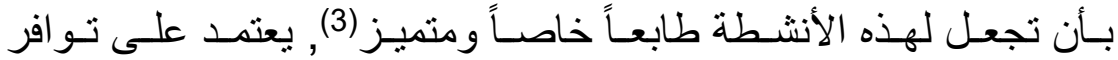

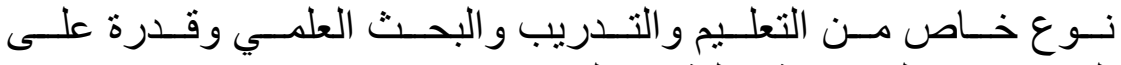

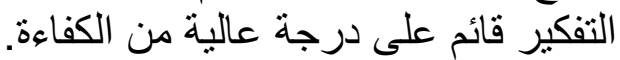

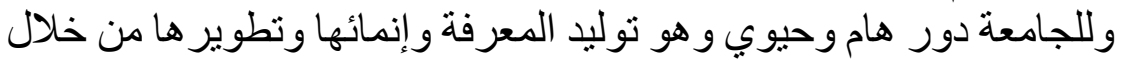

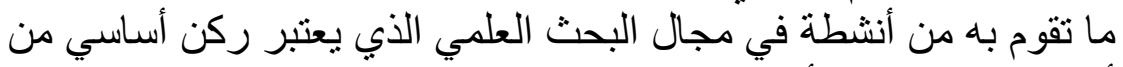

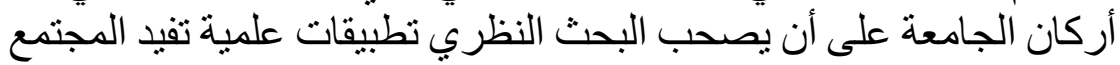
وهذا يقتضي وجود تعاون بين الجامعة بما فيها من إمكانية علمية متخصصة وبين المجتمع بمؤسساته المختلفة(10), ونتا ونتظم الجامعة

(1)ثروت عبد الحميدعيسى: أساليب الإستفادة من إدارة المعرفة بالمؤسسات التعلمية،

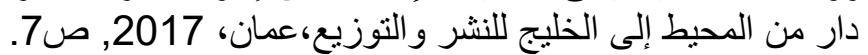

(2)ماهر عبد الهادي: دور الجامعة في التنمبية الإقتصادية والثانية الإجتماعية, الهيئية المصرية

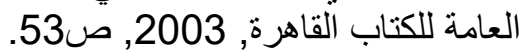

(3) Harad ,Harad," Difficulties in Diffusion of Tacit Knowledge in Organizations" ,journal of knowledge management ,vol 12,issue ,2000,p148.

Available

at:

https://www.researchgate.net/publication/200773019 Diff iculties in Diffusion of Tacit Knowledge in Organizati ons. ).Accessed at: 21-1-2020 (

(1)عبد الباسط محمد دياب: نطوير الإدارة الجامعية، العلم والإيمان للنشر والتوزيع،

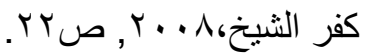
(2)(بيتر نايت، ترجمة خالد العامري: فن قيادة رئاسة القسم في الجامعة، دار الفاروق

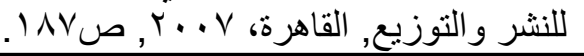




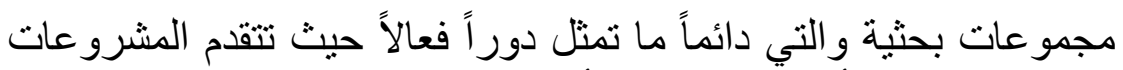

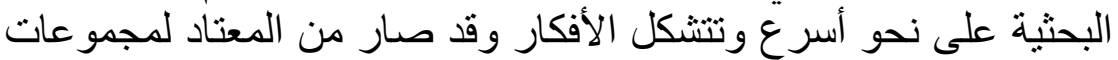

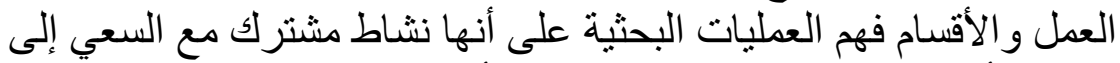

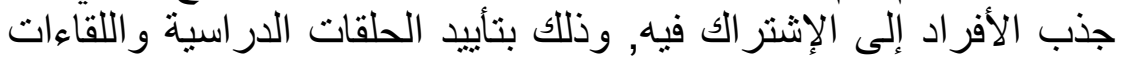

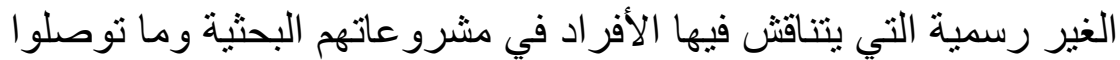

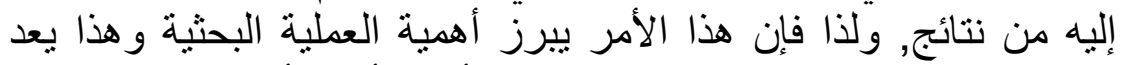

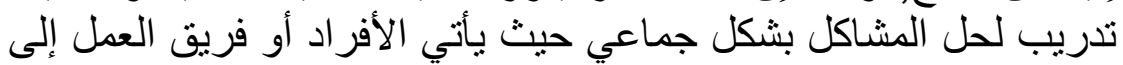

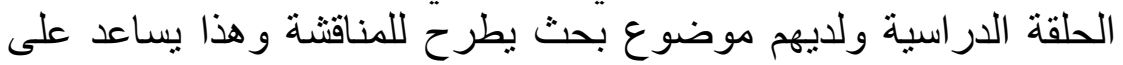
تشجيع الروح الإبداعية (2).

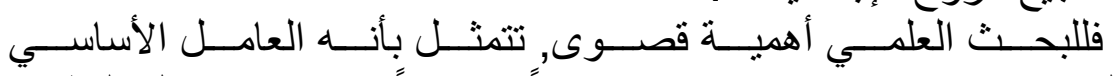

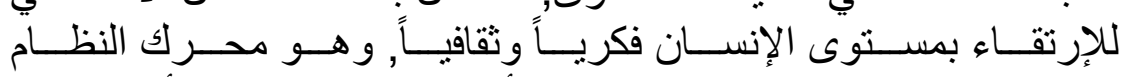

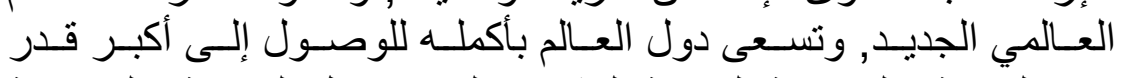

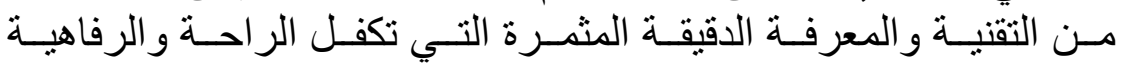
للشعوب في المجتمعات مهما تعددت والمعرة الختلفت ثنقافتها.

ثالثاً خدمة المجتمع في المجعات

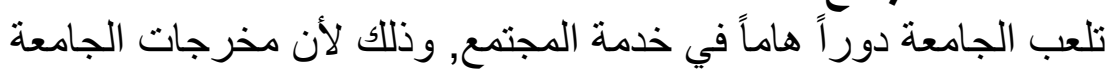

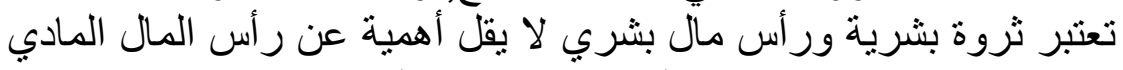

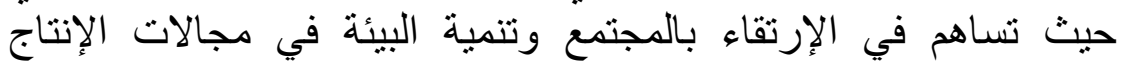

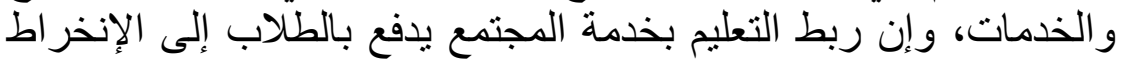

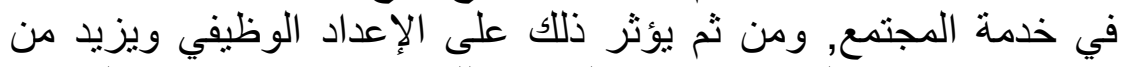

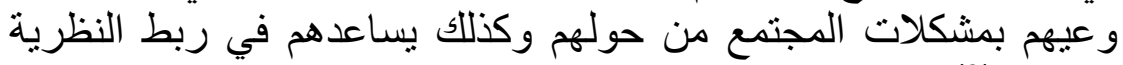
بالتطبيق(3). وتتوسع خدمة المجتمع لتشمل (نقل التقنية والابتكار ، المشاركة المجتمعية).

\section{أولاً نقل التقنية والإبتكار}

يتمثل هذا الدور في قيام الجامعة والارة بالعمل بإستمرار لكي تجعل العلوم

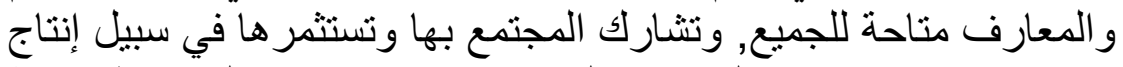

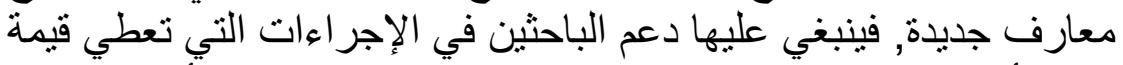

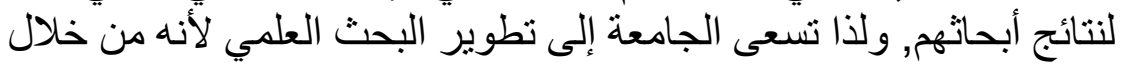

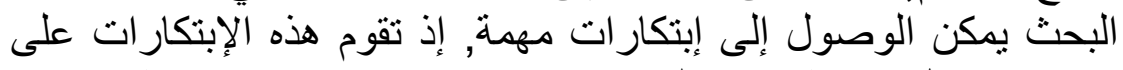

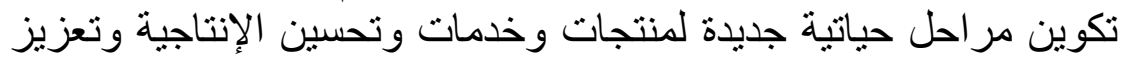

(3)طارق عبد الرؤوف عامر: الجامعة وخدمة المجتمع, نوجهات عالمية معاصرة،

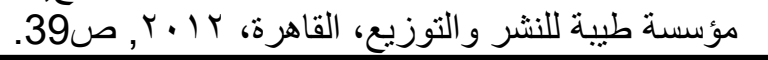


التنافسية وتوسيع نطاق الأسواق, فالإبتكار يشجع على خلق فرص وظيفية

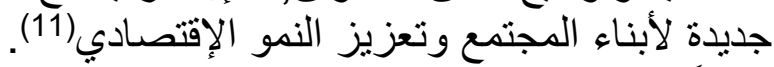
ثانياً المشاركة لأنياء المجتمعية

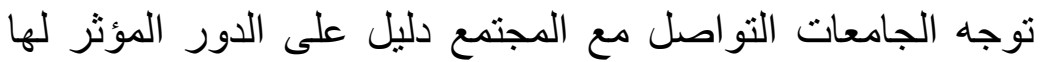

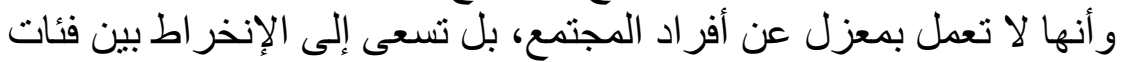

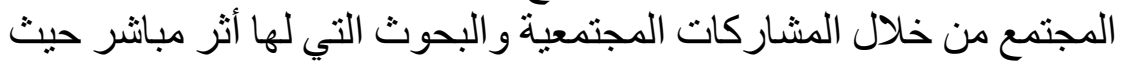

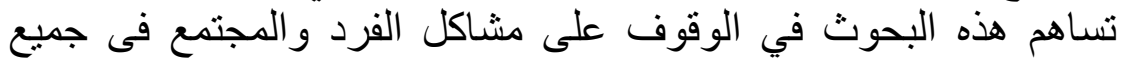

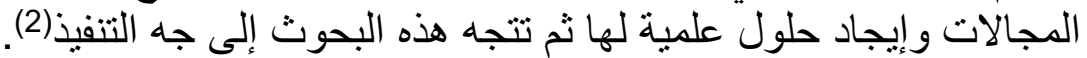
2) مفاهيم جديدة فرضها التطور العلمي للجامعات. (مفهوم الحرية الأكاديمية، مفهوم التعليم المستمر ، مفهوم الإنسان

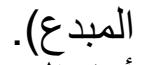
أولا الحرية الأكاديمية المبية من أهم المتطلبات الواجية الإدية توافرها في العملية البحثية هى الحرية

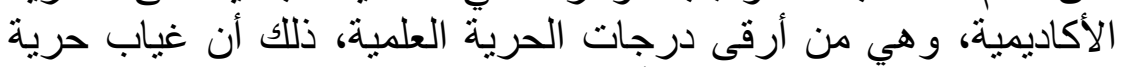

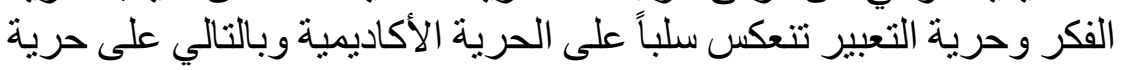
البحث العلمي. وتعرف الحرية الأكاديمية بأنها "حرية التفكير لأساتذة الكليات و الجامعات

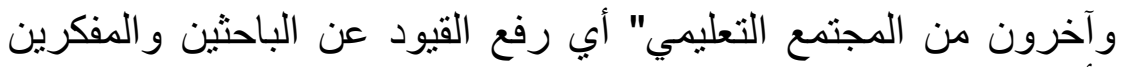

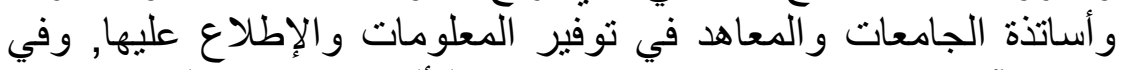

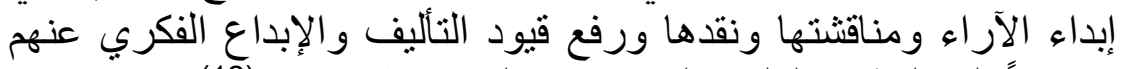

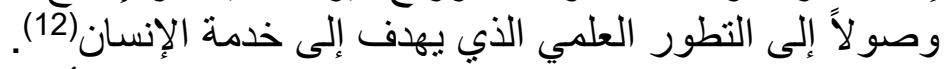

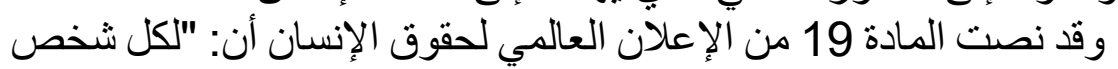
الحق في حرية الر آي و التعبير , ويشمل هذا الإنا الحق حرية إعتناق الأفكار دون الأن

(1) وزارة التعليم العالي ــوكالة الوز ارة للتخطيط و المعلومات ـالإدارة العامة للتخطبط:

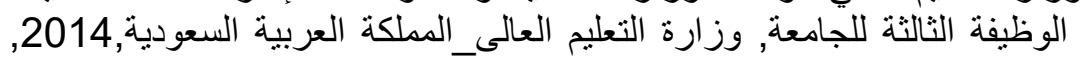

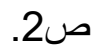

(2)Tamas,R.Black: understanting social science research, SAGEpublication, London, 2002, p32.

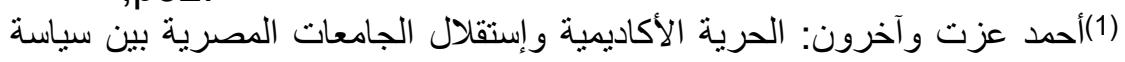

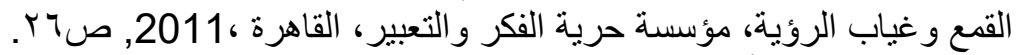

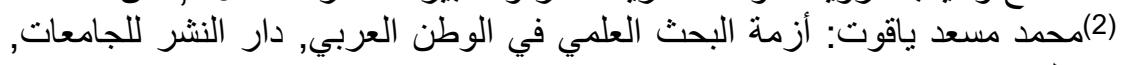

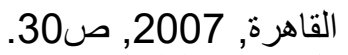
(3) عادل سعيد: كفاءة التعليم المستمر وكيفية تحقيقها في مجتمع المعرفة من وجهة نظر أعضاء هيئة تدريس كلية تربية في المملكة

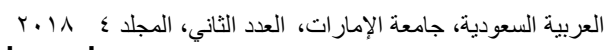
(4)شادية حسن فتحي: التعليم المستمر ودوره في التتمية البشرية, دار المعارف للنشر والتوزيع, الإسكندرية, 2009 صالبة ص9. 
تدخل و إستقاء الأنباء والأفكار وتلقيها و إذاعتها بأي وسيلة كانت دون تقيد بالحدود الجغر افية" (2).

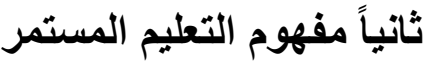

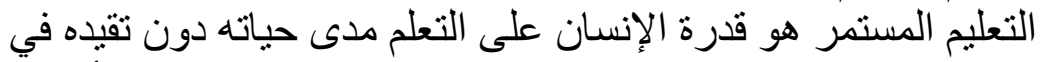

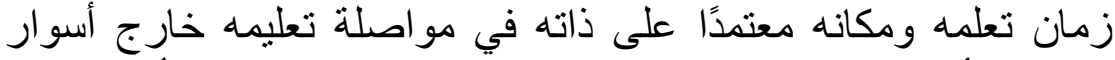

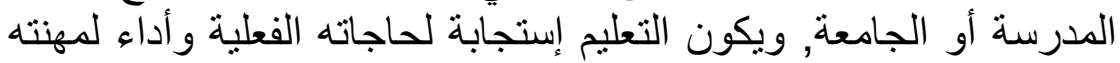

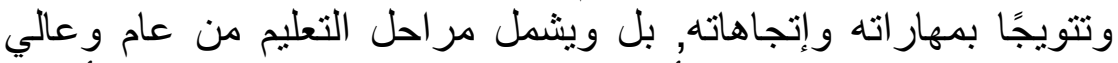

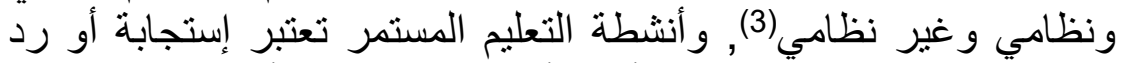

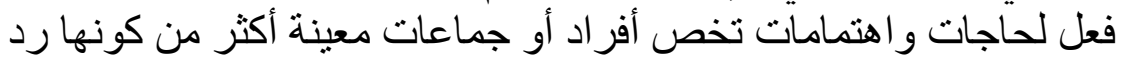
فعل لهذف أو خطة موجهة. وتتمثل بعض هذه الأهداف(الكفاءة الوطنية المهنية والحرفية, الكفاءة في

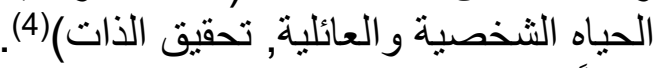

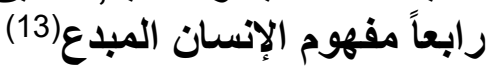

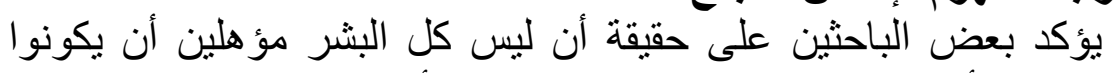

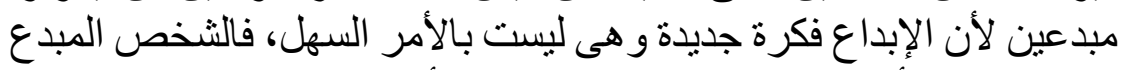

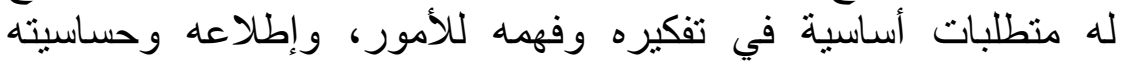

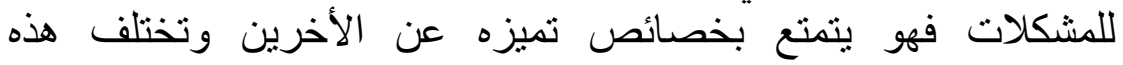

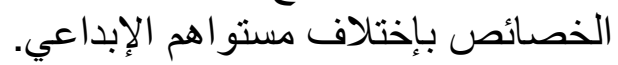
والإنسان المباع هو الذي لإني يعيق طاقة الإبداع الفكرية لديه ويوجه قدر اته نحو مختلف مجالات الان الحياة. 3) الجامعة كمجتمع معرفة مجنة

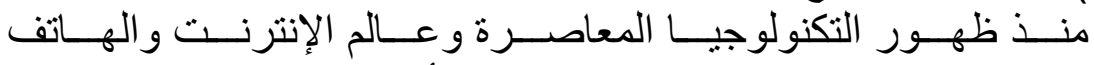

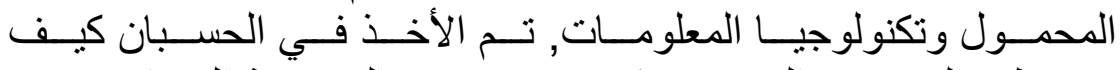

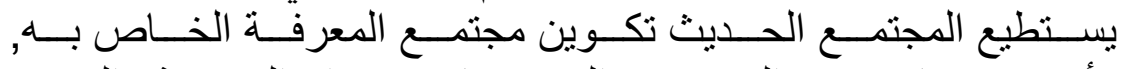

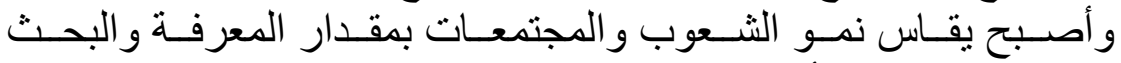

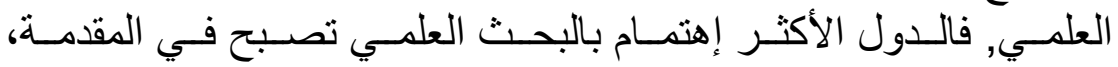

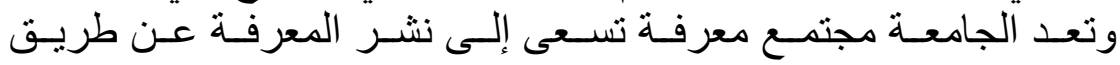

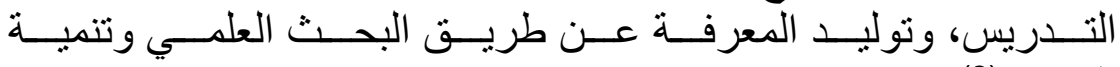

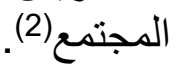

(1)كارول جومان, ترجمة باهر عبد الهادي: دليل علمي في التفكير الإبداعي, دار

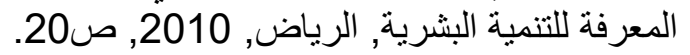

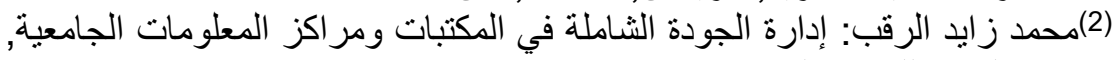

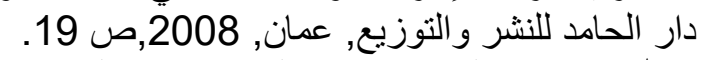

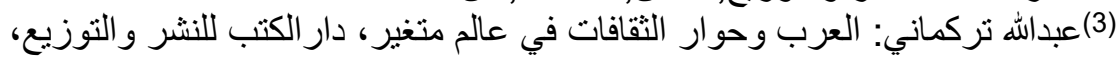

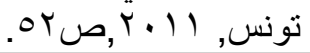




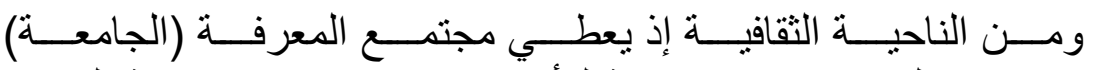

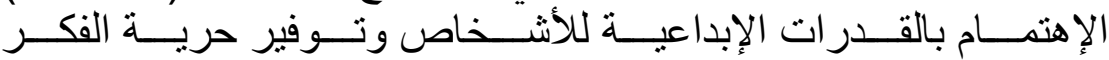

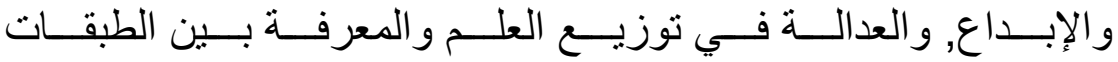

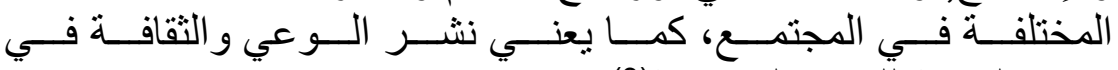

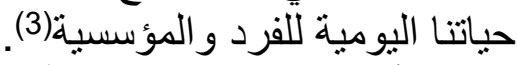

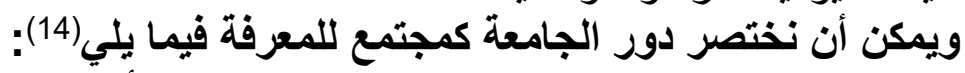

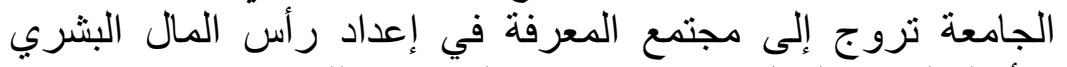

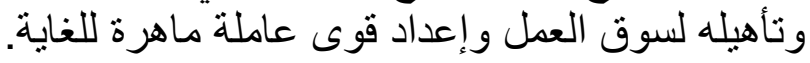

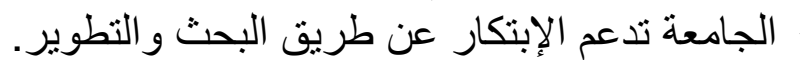

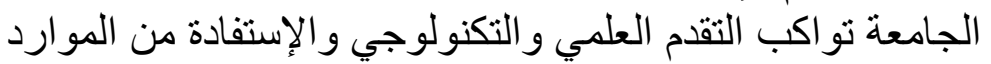
المتاحة. و ولا يتبع الإنتاج المعرفي للجامعات فحسب ولكن في معامل الصناعة

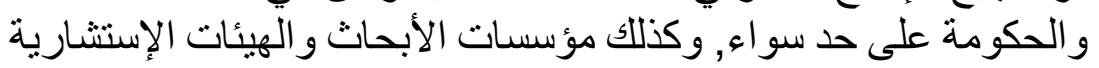

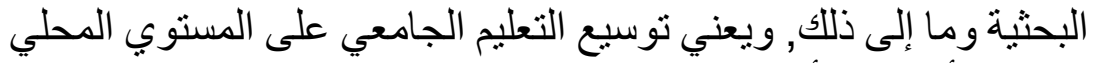

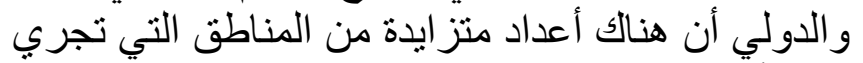

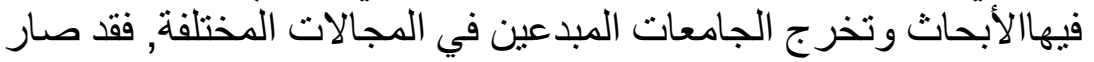

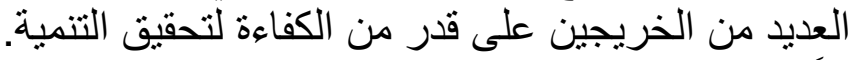

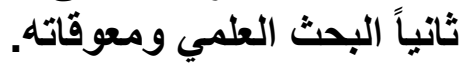
يعد البحث العلمي المدخل الجوهي هري لتحفيق التهيث التنمية المستدامة, وأي

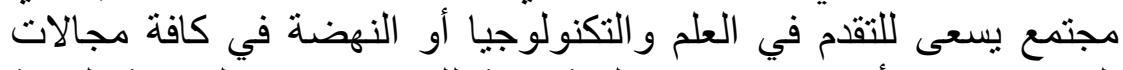

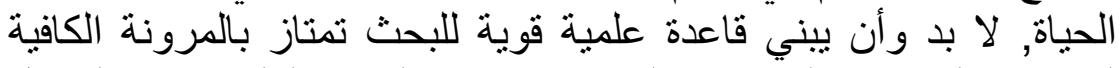

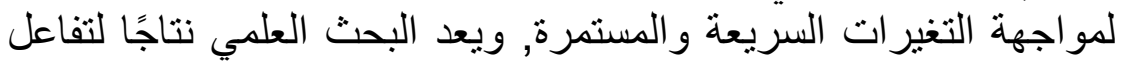

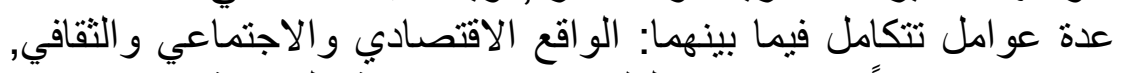

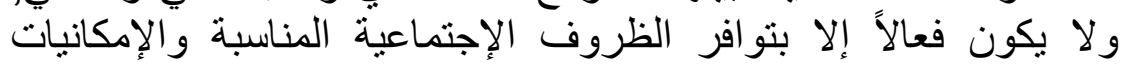

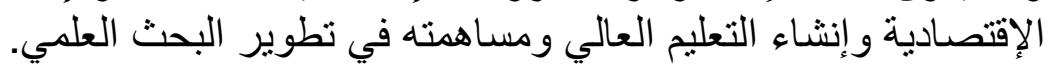

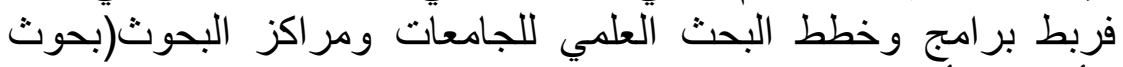

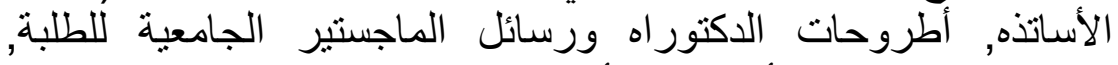

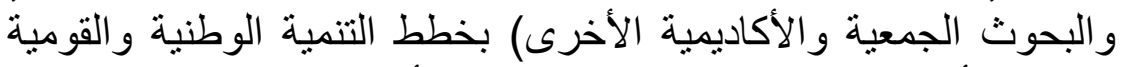

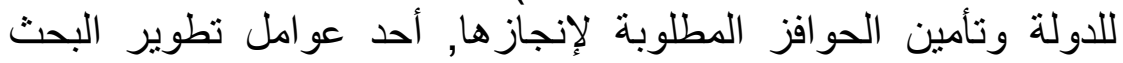

(1)David M.Hoffman,jussi valimaa: higher education institutions in network knowledge societies, Springer,newyourk, London,2014,p20

(2)محمود كاظم التميمي: كتابة البحوث والرسائل في العلوم التربوية والنفسية, دار الصفاء للنشر والتوزيع, عمان, 2013, ص النية 30. 
العلمي, وبعبارة أوضح من الضروري أن تنسجم البحوث الجامعية

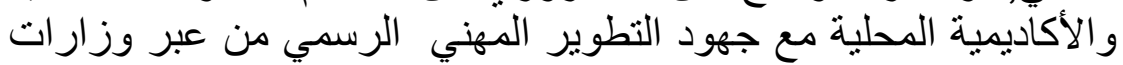

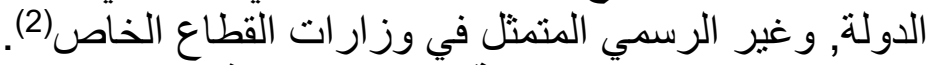
ويمكن تحديد عناصر منظومة البحث العلمي في مصر وهما:

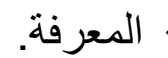

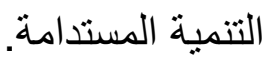
كإن الإبداع و الإبتكار.

وتعددت معوقات البحث العلمي, ويمكن عرض بعض من هذه المعوقات

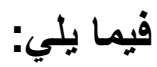

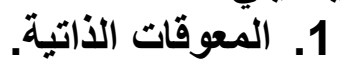
2. المعوقات المادية.

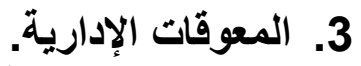
4. 3. المعوقات السياسية. 5. المعوقات العلمية والثقافية المبية.

أولاً: المعوقات الأذاتية.

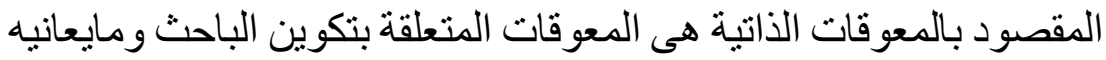

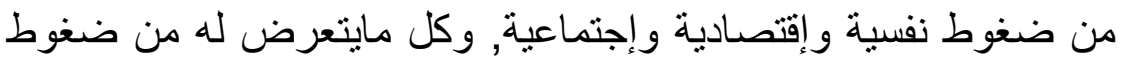

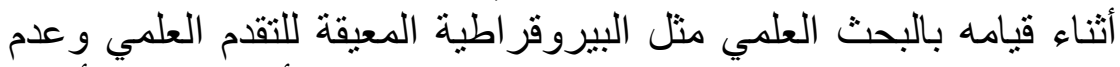
القدرة على تكوين مجموعات بحثية والإنفاق عليها, وأيضا تتعلق بأماتنة

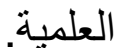
وتتضح المعوقات الخاصة بالأمانة العلمية للباحث فيما يلي(15): ثانياً المعوقات المادية.

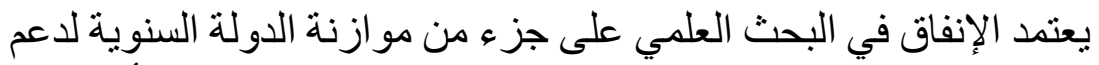

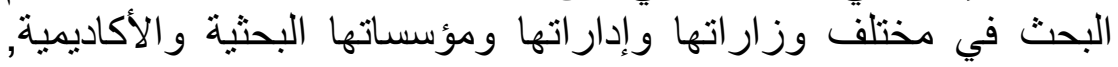
ومساهمة من القطاع الخاص الصناعي كثركات الإتصالات والهات والهندسة

\footnotetext{
(1)علي إبر اهيم علي عبيدو: جودة البحث العلمي(الأخلاقيات, المنهجية, الإشر اف), دار

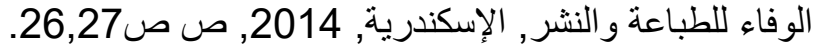


و البنوك و على هذين القطاعين أن يكملا بعضهم البعض في تمويل البحث و التطوير (16). و إنفاق المؤسسات الإنتاجية على البحث العلمي تكون أول المستفيدين بهاه

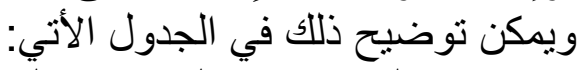

جدول (1) مردود التعاون بين التجامعات والمؤست الجسات الإنتاجية(2).

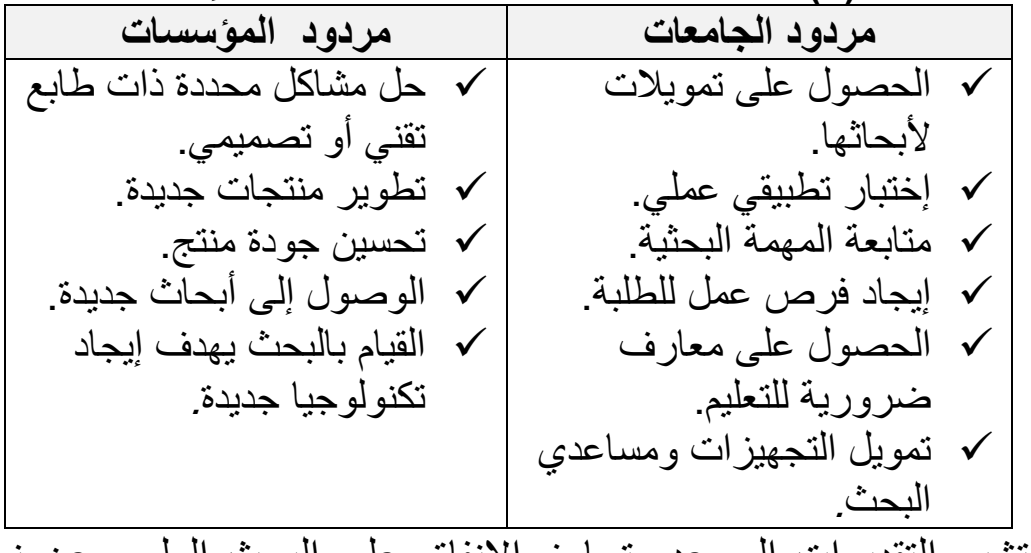

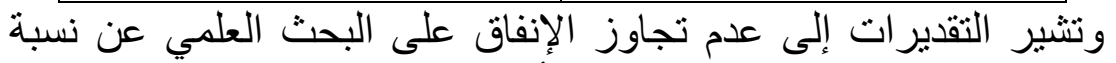

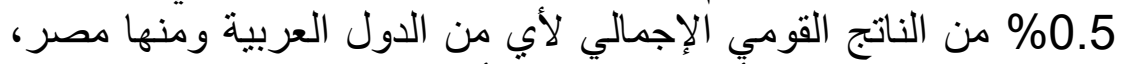

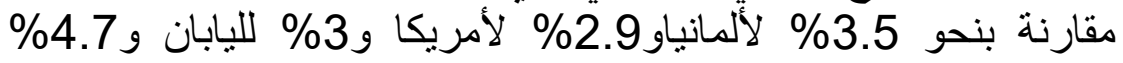

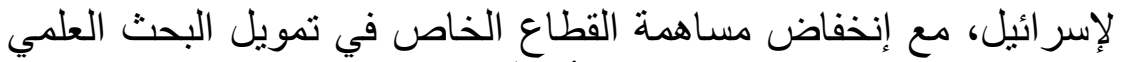

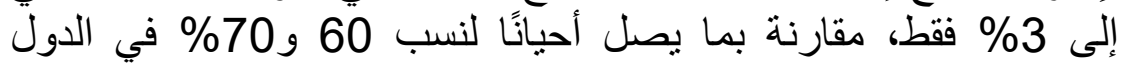

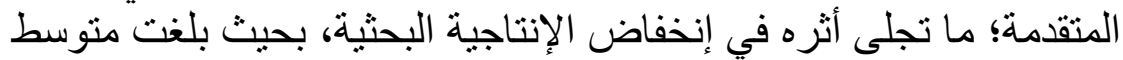
0.2 بحث فقط للباحث العربي مقابل متوسط الخفادة 1.5 بحث للباحث في الدول

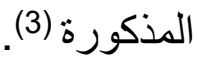

وضعف تمويل البحث العلمي وغياب الدعم المالي وسوء تسبير الميزانية

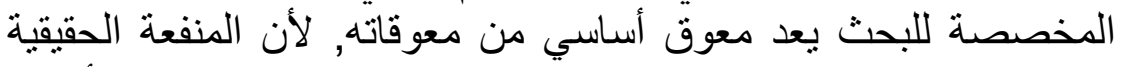

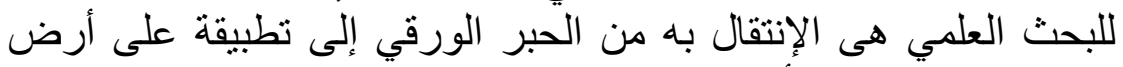

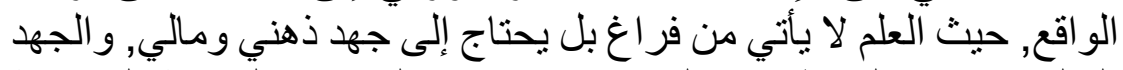

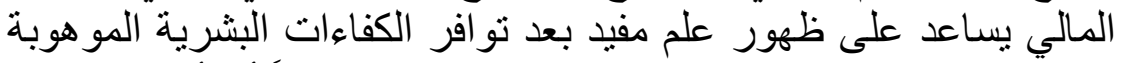

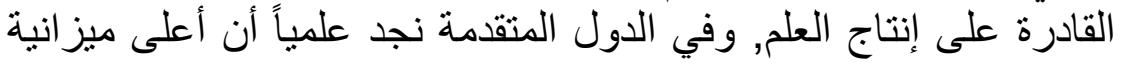

(1) محمد مسعد ياقوت: أزمة البحث العلمي في الوطن العربي, مرجع سابق ذكره ص143. (2) عبد الرحمن عامر: رأس المال المعرفي, مرجع سابق ذكره ,ص223.

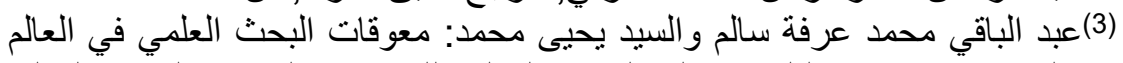

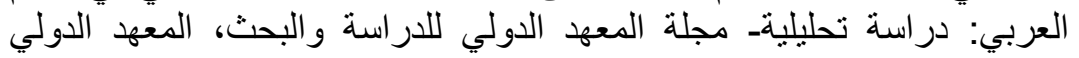

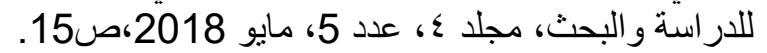


هى ميز انية البحث العلمي في حين مرتبة متأخرة عند الدول الفقيرة, ولكننا

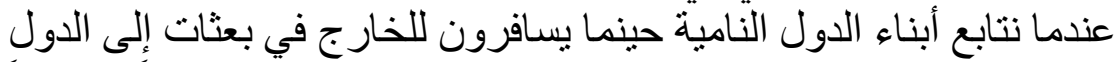

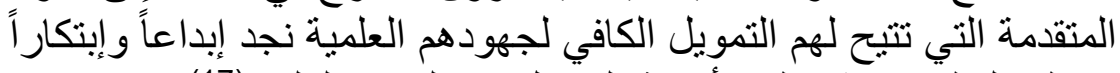
منقطع النظير وهذا يظهر أهمية التمويل في البحث العلميل(17).

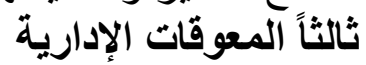
إن تبني الدولة لرؤية إستر اتيجية محددة المعالم و الأهداف و الوسائل للبحث

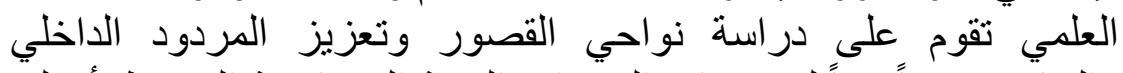

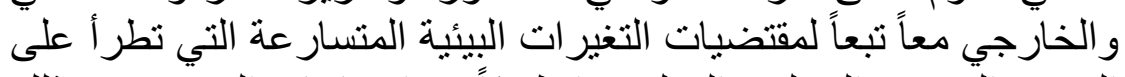

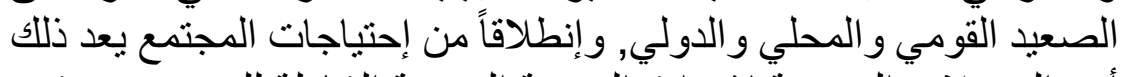

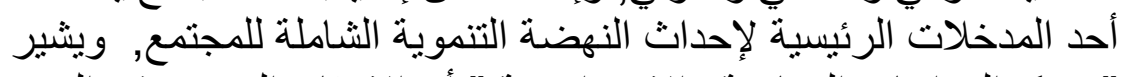

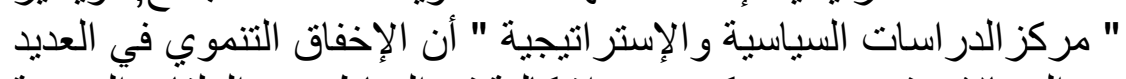

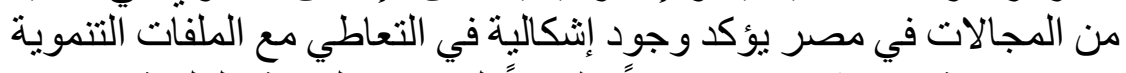

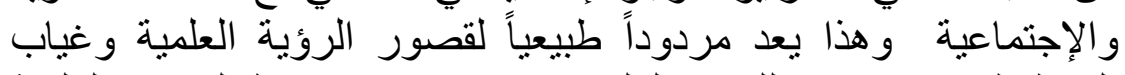

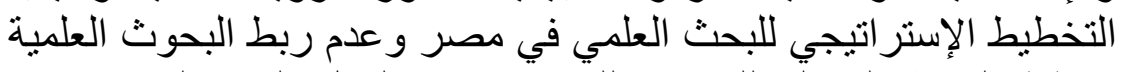

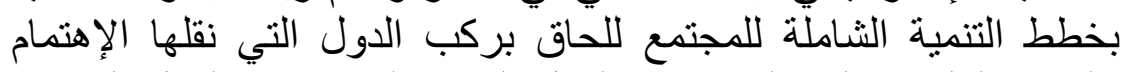

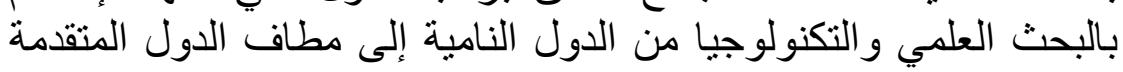

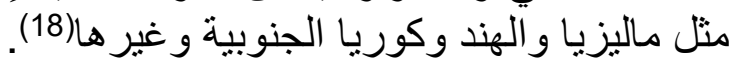
ولعل السبب الرئيسي لغياب الروئية الإستر اتيجية للبية للبحث العلمي في مصر:

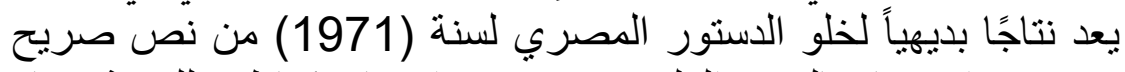
يستوجب الإهتمام بالبحث العلمي وتشجيعه و إعتماده كقاطرة للتنمية وبناء لإنه

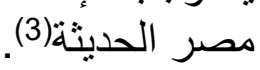

ولكن تغير ذلك في دستور 2014م في المادة 23 والتي نصت على:

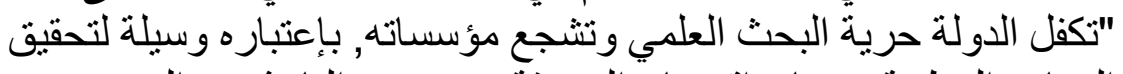

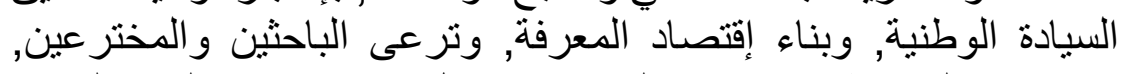

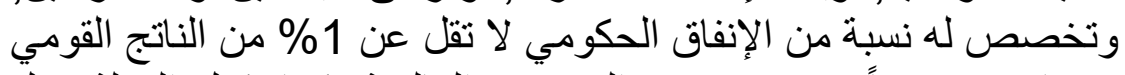

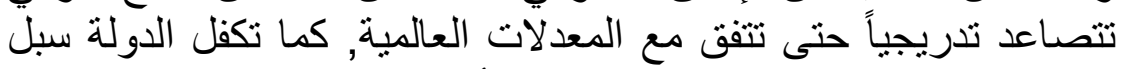

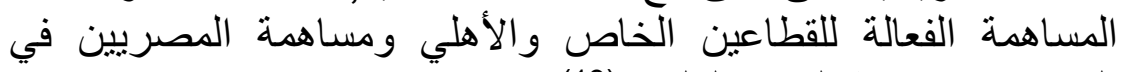
الخارج في نهضة البحث العلمي"(19).

(1)عبد الخالق محمد عفيفي: منهجية البحث العلمي في الخدمة الإجتماعية, المكتبة

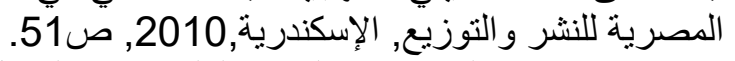

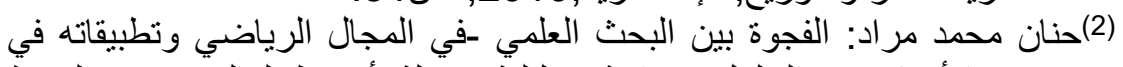

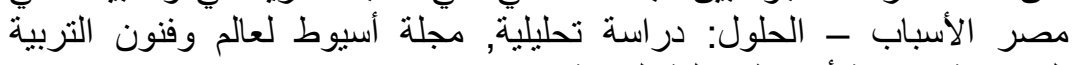

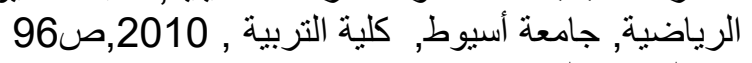

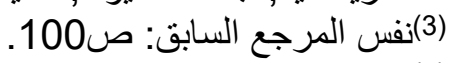
(1)دستور مصر 2014: جمهورية مصر العربية, صوبن. 


\section{رابعا المعوقات السياسية}

في نطاق البحث العلمي فإن أب وحدة بحثية لا تعمل وفق هو الها الها بل تعمل

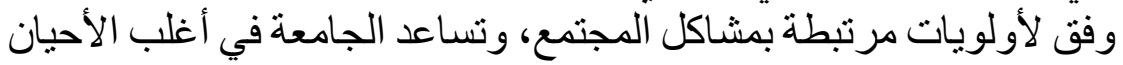

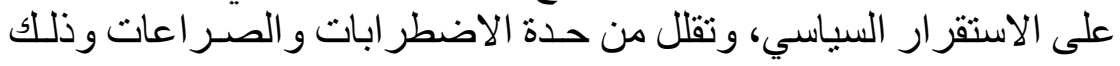

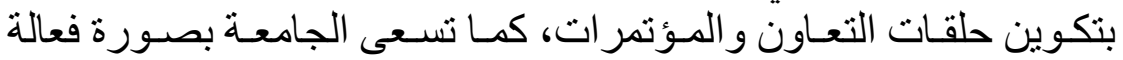

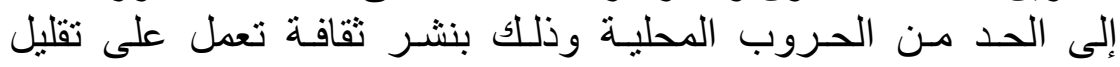

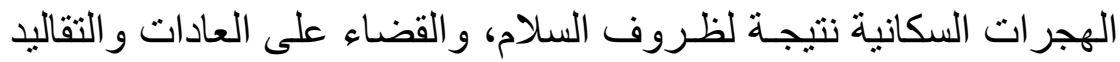

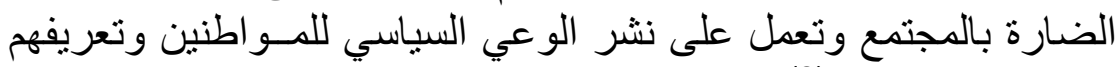

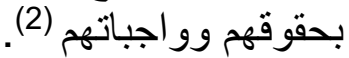
وإن حرية البحث العلمي مرتبطة بالنظام السياسي السائد وبسياقه

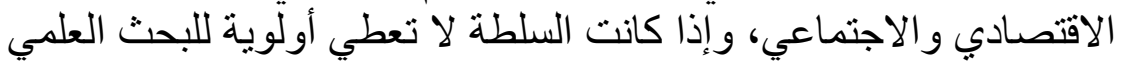

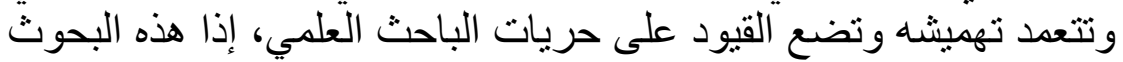

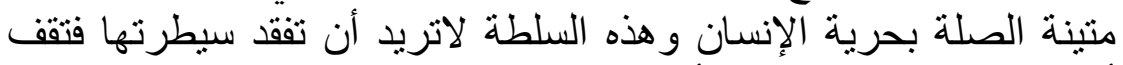

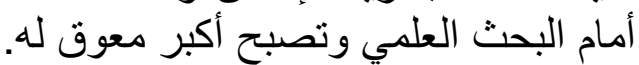

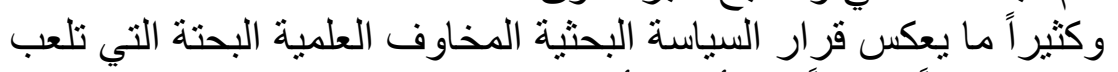

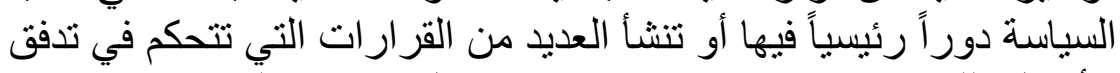

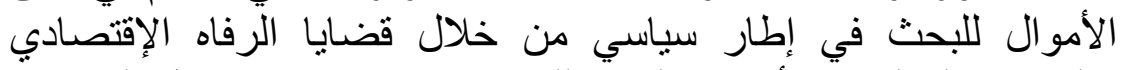

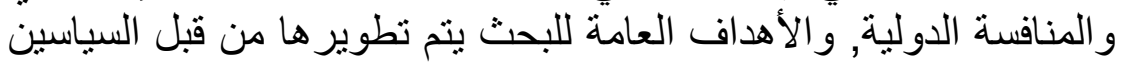

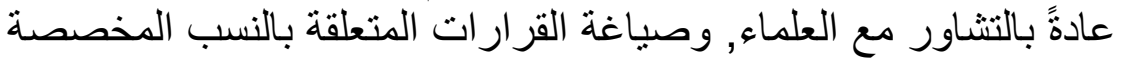

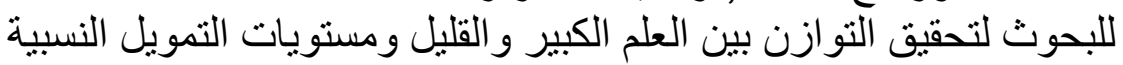

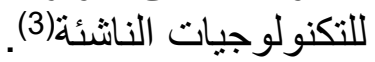
ثالثاً دور الجامعة في تظوير البحث العلمي وتنمية المجتمع.

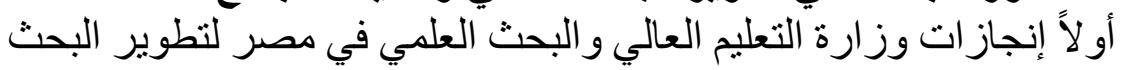
العلمي "مؤشر ات العلوم و التكنولَو جيا و الابتكار "(20).

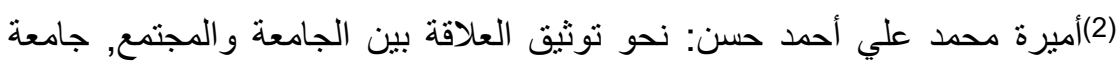

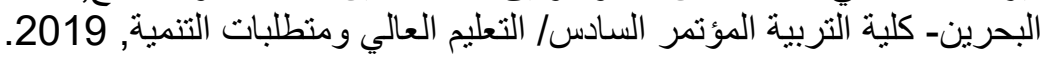

(3) Report of a Symposium Government-University-industry: Future National Research Policies Within the Industrialized Nations, National Academy Press, Washington, D.C, 1992,p3.

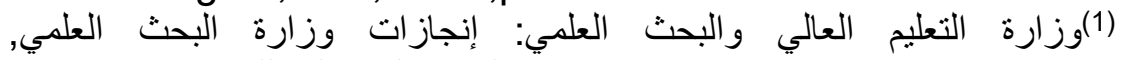

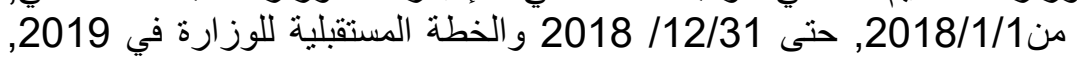
(2)وزارة التخطيط والمتابعة والإصلاح الإداري: إستراتيجية التنمية المستدامة "رؤية

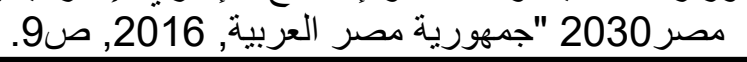


جميع المؤشرات المتعلقة بمدخلات ومخرجات العلوم والتكنولوجيا والابتكار (طبقاً للمعايير الدولية) في تحسن يتر اوح ما بين تدريجي وكبير

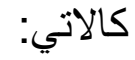

1. وصل الإنفاق على البحث العلمي والتطوير إلى 19.19 ملئ مانيار

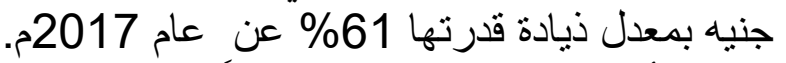
2. بلغت الأبحاث العلمية المنشورة دولياً 18777 معام معدل زيادة قدرتها 29\% عن عام 2017م. 3. إحتلت مصر المرتبة 38 عالمياً في مجال الأبحاث العلمية

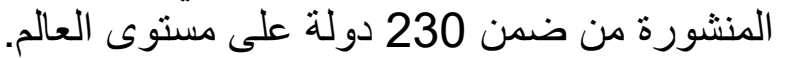

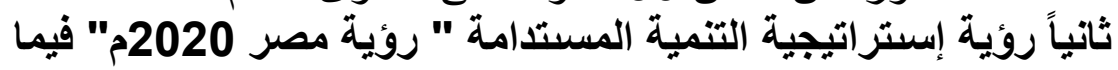

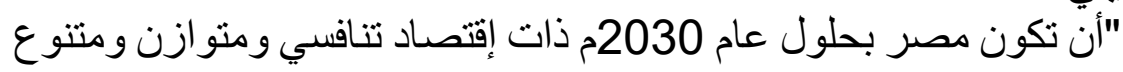

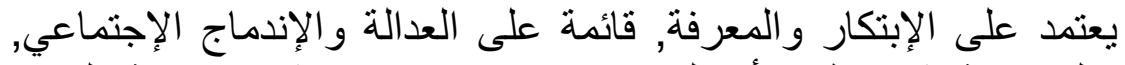

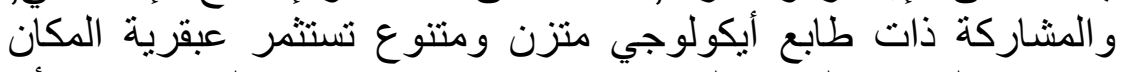

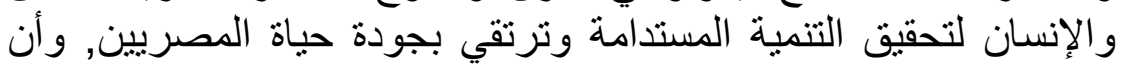

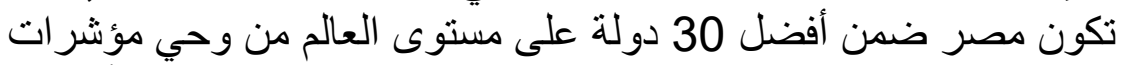

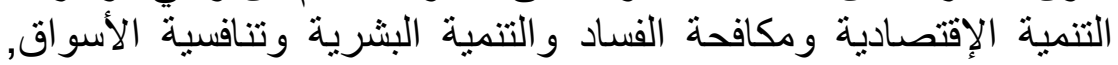

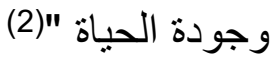

الأهداف الإستر اتيجية للتعليم الجامعي أو العالي حتى عام 2030م(3).

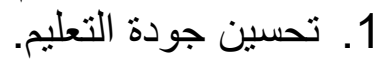

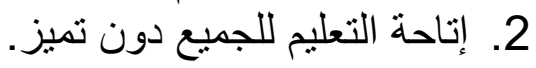

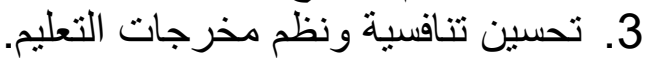

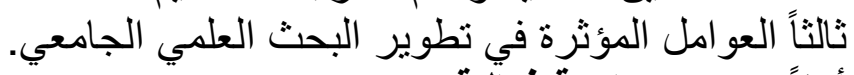

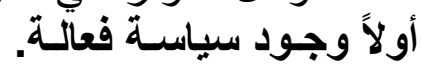

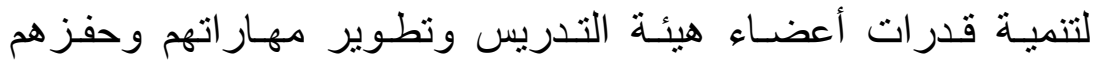

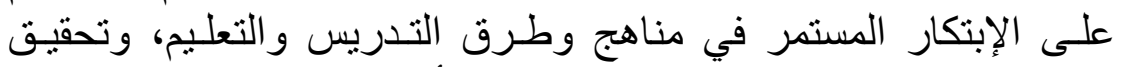

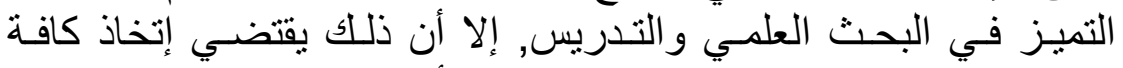

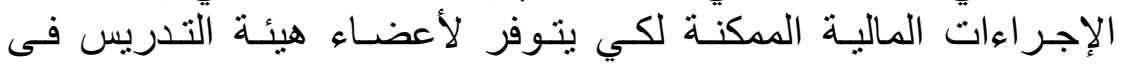

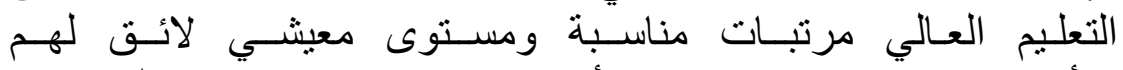

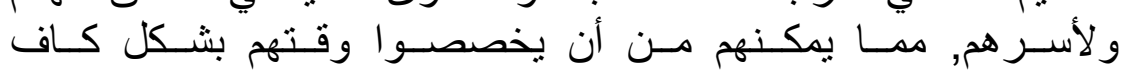

(3) قطاع الثئون الاجتماعية والثقافية: وثيقة تقارير مصرية حكومية، وزارة التخطيط، منوفر على:

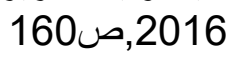
ص, 2021-2-1 https://manshurat.org/node/13707 تم الوصول. 


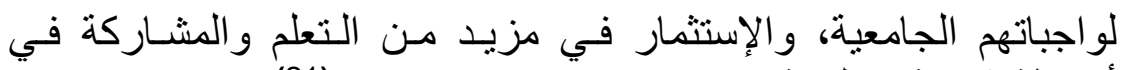

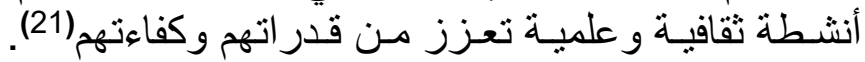

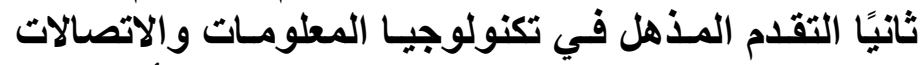

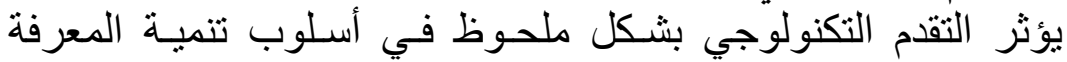

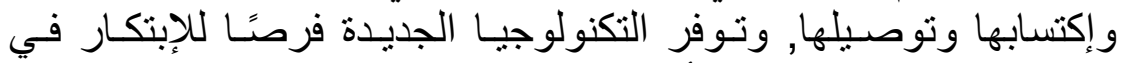

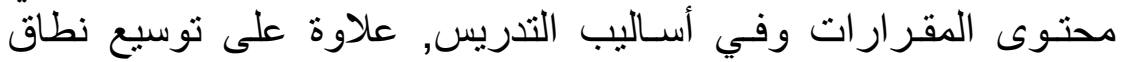

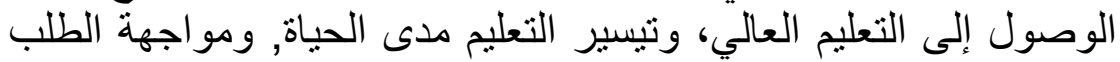

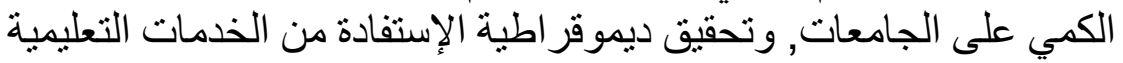

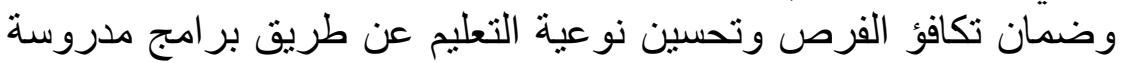

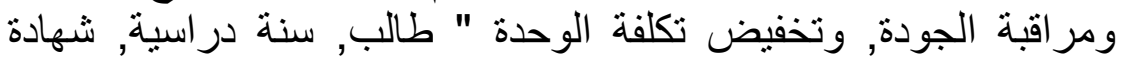

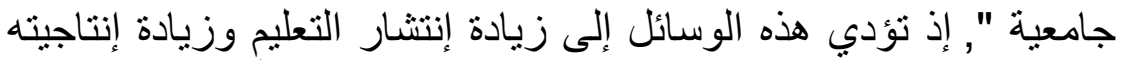

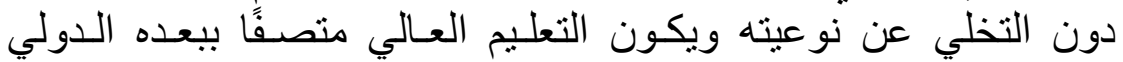

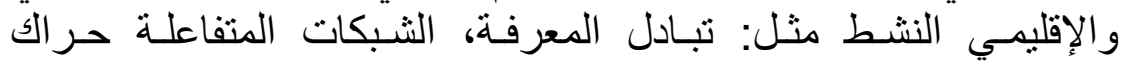

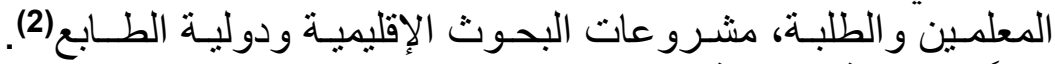
ثالثاً استقلالية الجامعة المبة:

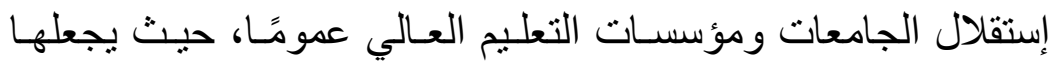

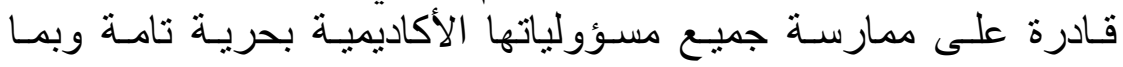

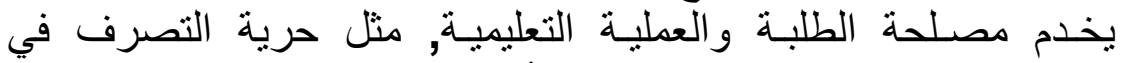

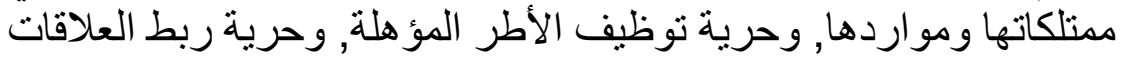

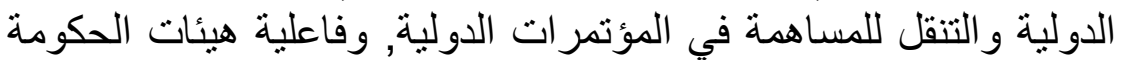

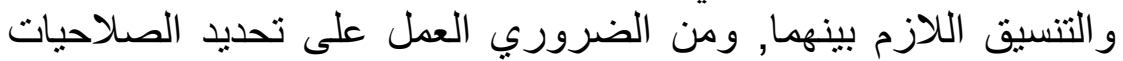

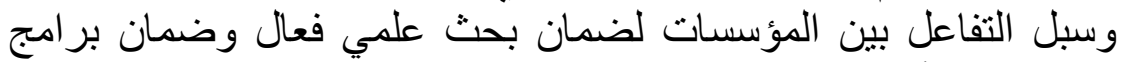

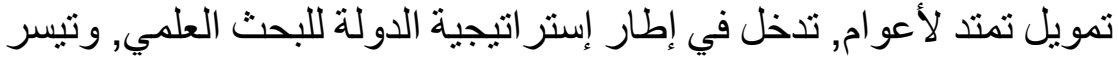

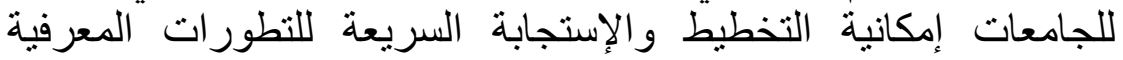

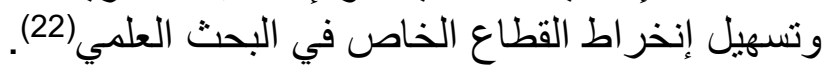
رابعاً الإدراة الفعالة والمؤثرة

(1)محيي زيتون: رؤية للتعليم العالي في مصر من منظور الجودة و العدالة, مركز

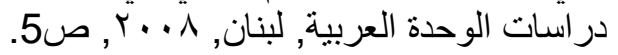

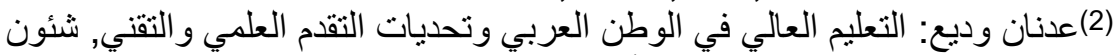

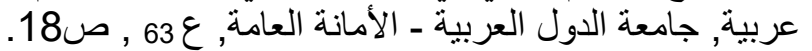
(1)إبر اهيم فريد: الجامعات و البحث العلمي في العالم العربي, المركز العز العربة العربي للأبحاث

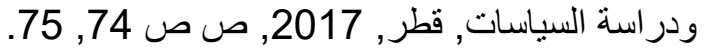

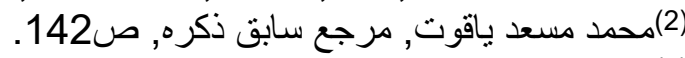

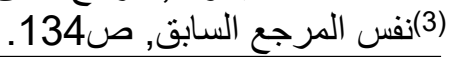


لتحقيق أهداف البحث وتطويره لابد من وجود إدارة جامعية مرنة وفعالة

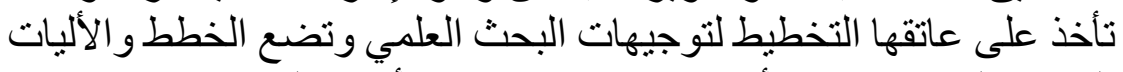

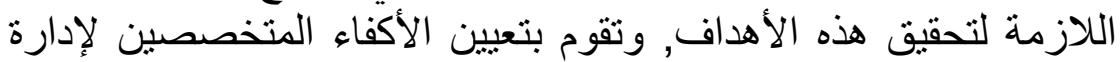

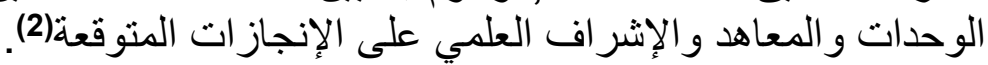

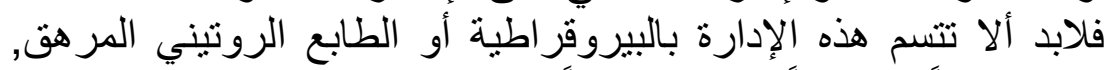

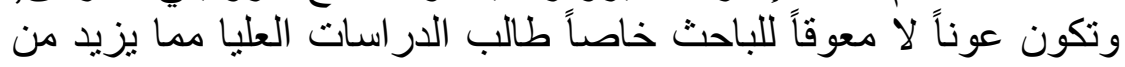

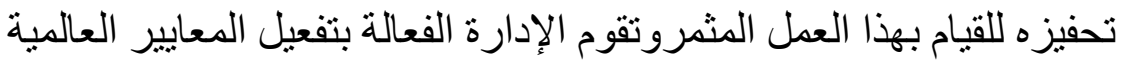

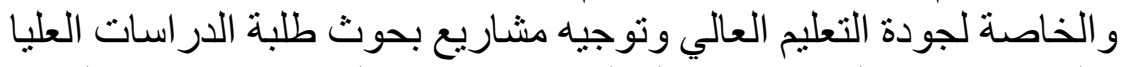

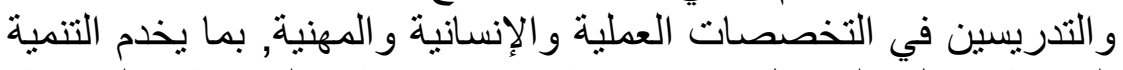

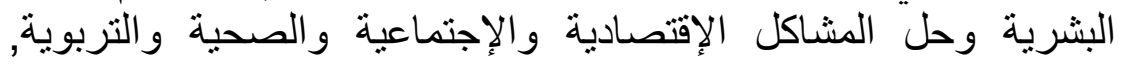

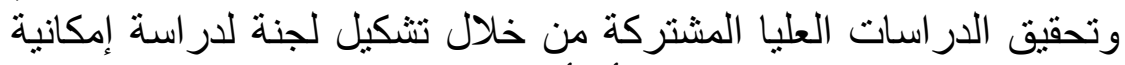

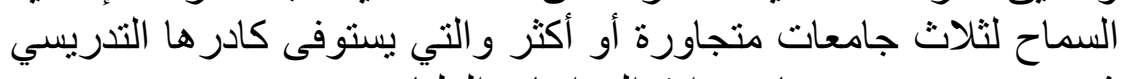

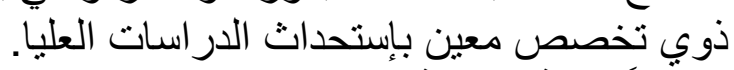

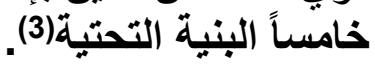

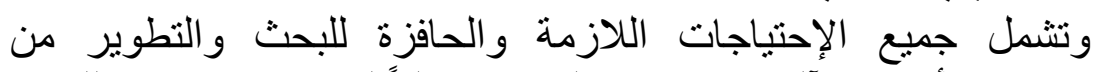

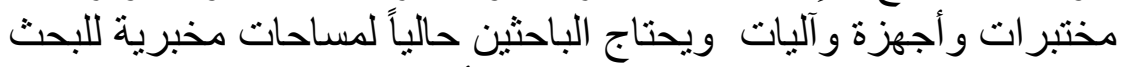

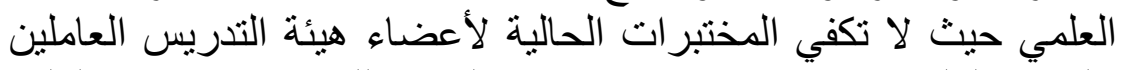

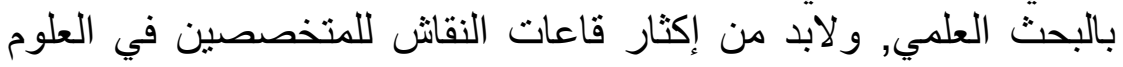

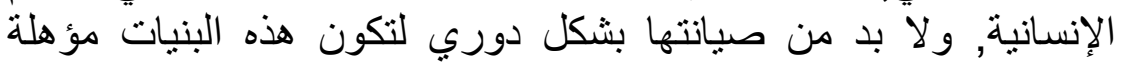
لإجر اء البحوث بكفاءة وسلامة ولإنة وسلاسة.

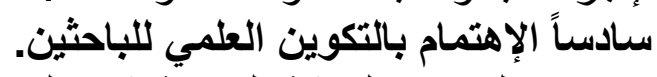

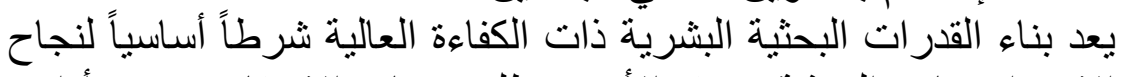

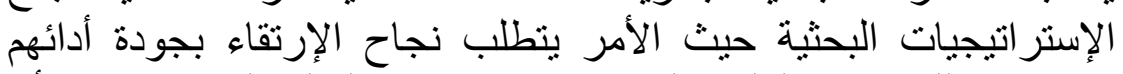

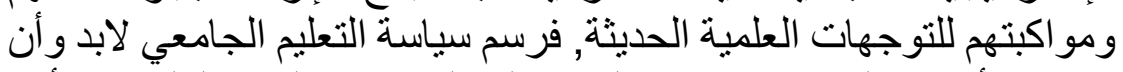

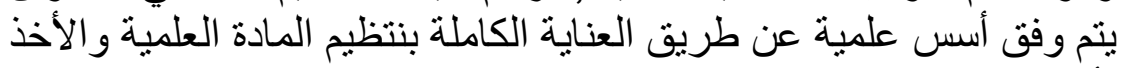
بأحدث الطرق لتوصيل المعلومات للباحثين(23), وإعداد كفاءات بشرية العنة

(1)أحمد بدر وآخرون : المكتبات الجامعية تنظيمها و إدارتها وخدماتها ودورها في

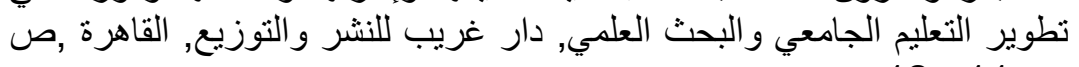
ص 11 , 12.

(2)نبيل محمود عبد العظيم: دور البحث العلمي و التقنى في تطوير المجتمعات النامية

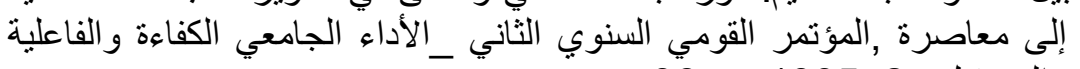

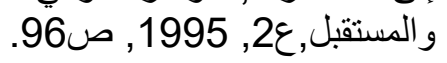
https://search,mandumah.com/Record/398184 منوفر على: (تم الوصول في:27-1-2021). 


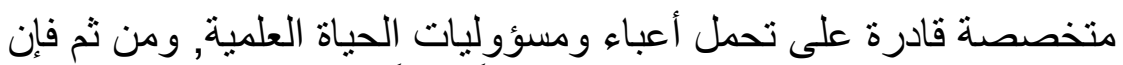
الجامعة تزود المجتمع بالقوة المؤهلة تأهيلاً عالياً وقادرة على المساهمة في فلي عملية التنمية. ويتحقق ذلك منذ المرحلة الجامعية الأولى يتعلم طالب الجامعة قوانين

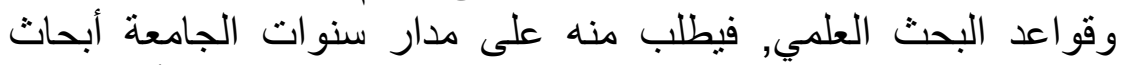

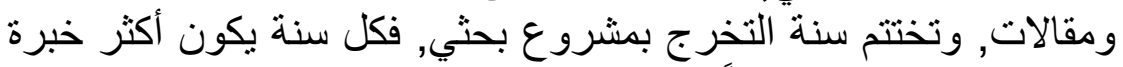

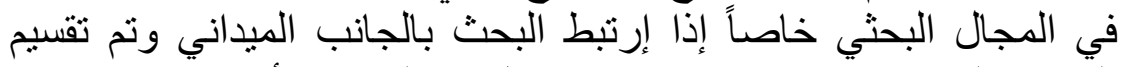

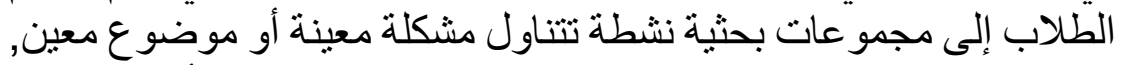

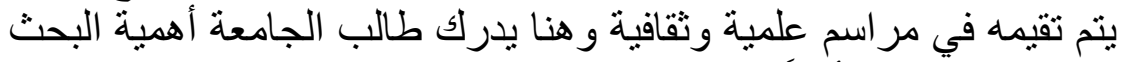

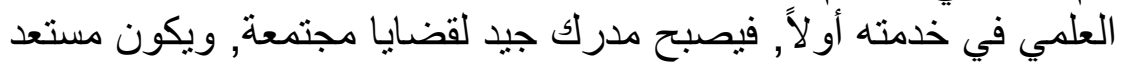

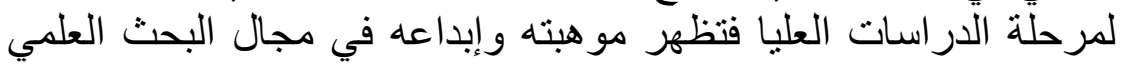

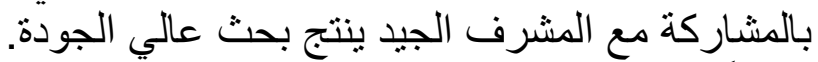

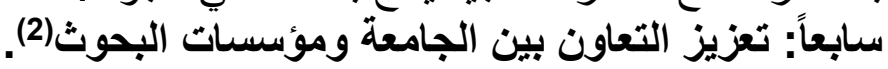

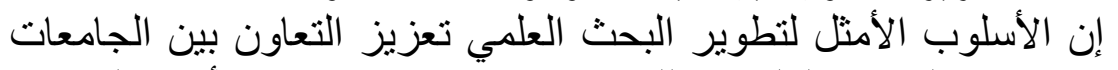

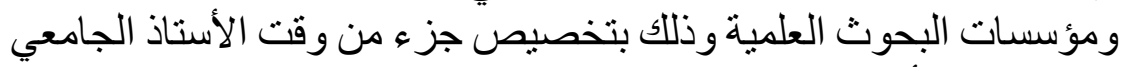

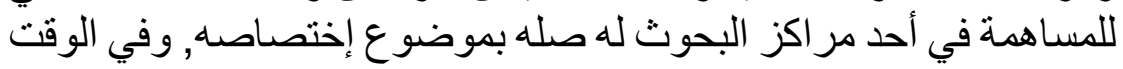

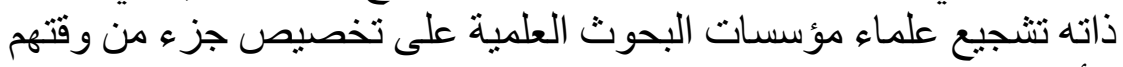
الأسبو عي للمساهمة في التدريسات الجامعية, وسيعود ذلاتلك بالفائدة على على كل

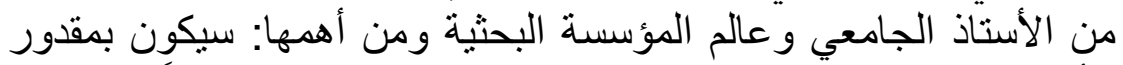

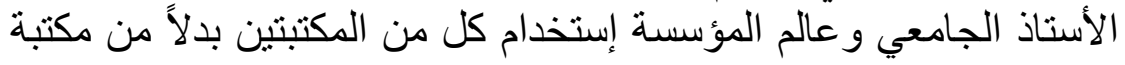

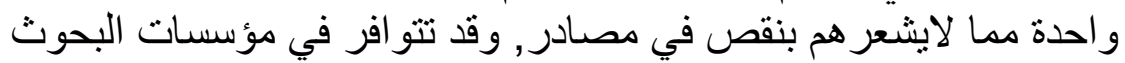

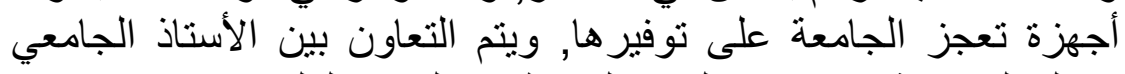

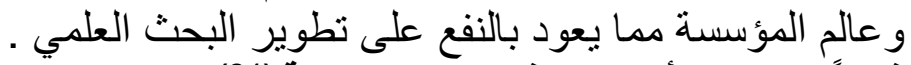

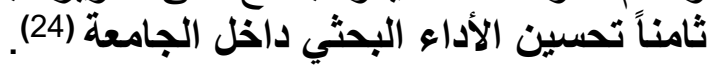

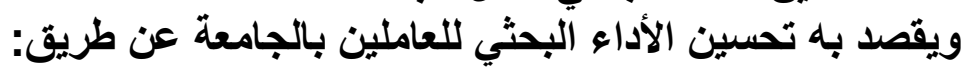
1. إقامة دور بات علمية وثقافية مكثة في ميادين فلسفة العادئ العلم ومناهجه. 2.

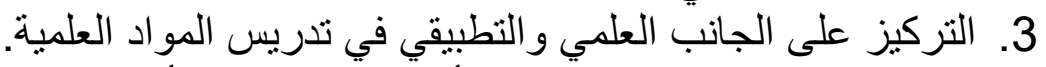
4. تثجيع طلاب المرحلة الجامعية الأولى على القيام بالأبحاث العلمية لكية

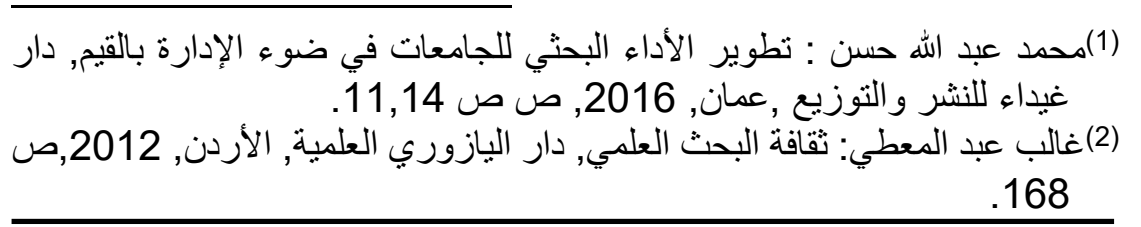


5. تشجيع إجر اء البحوث العلمية بما في ذللك الأبحاث التي تتضمن الدرجة العلمية.

6. التدريب على إستخدام الوسائل التكنولوجية المتطورة.

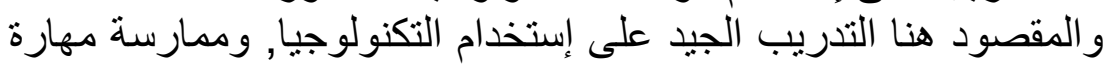

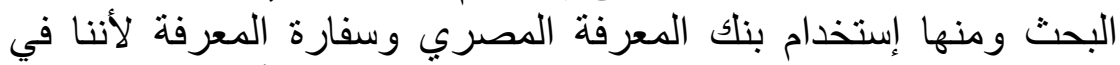

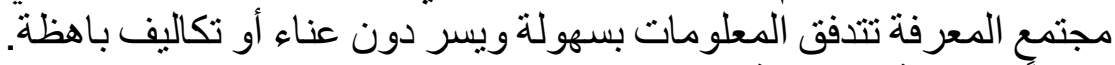
تاسعاً: المكتبة الجمامعية. تعد المكتبة الجامعية إحلى المرامية المبلى الحيوية في التعليم الجامعي لأنها

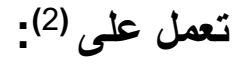
1. رفع كفاءة الطلبة وتمكينهم من الإستفادة من خدماتها المختلفة (الإعارة

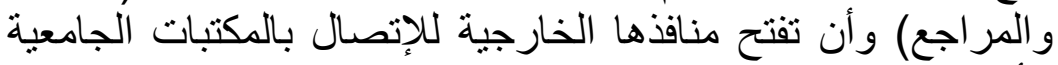

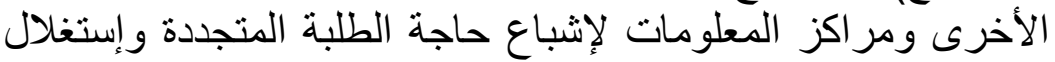
أوقات فر اغهم بنشاط رشئ اكنيد بناء.

2. عقد دور ات تدرييية مستمرة للطلبة للتعرف على على أخر المستجدات و البحوث العلمية و التكنولوجية.

3. ربط المكتبة الجامعية بشبكة محلية مع المكتبات الجنة الجامعية المتقاربة

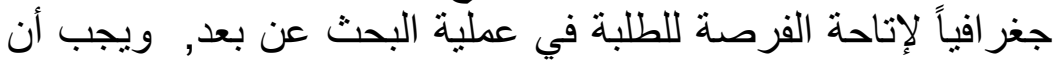

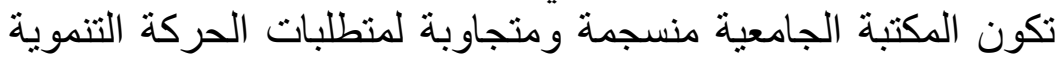

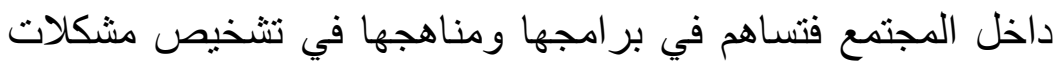

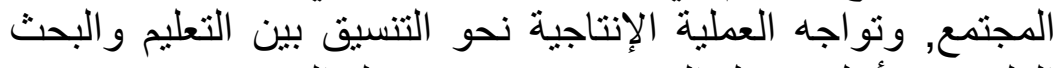

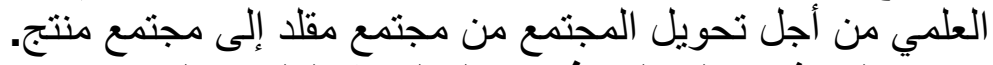
4. تدريب الباحثين والعاملين في مجال البحث العي العلمي على على إستخدام

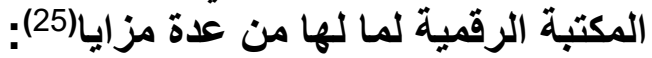

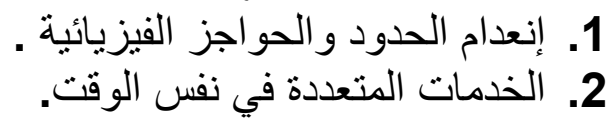

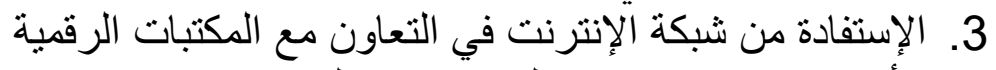

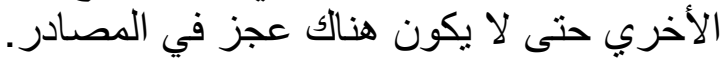

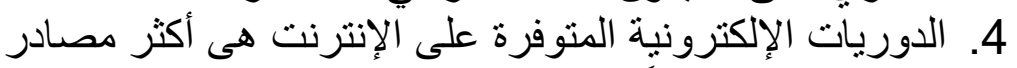

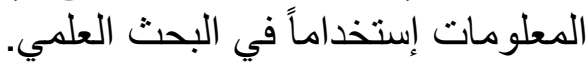

(1)عبد الغني محمد إسماعيل: دليل الباحث إلى إعداد البحث العلمي, دار الكتاب

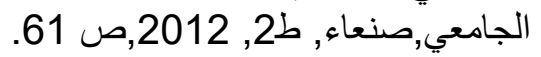

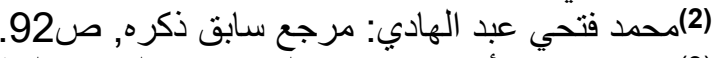

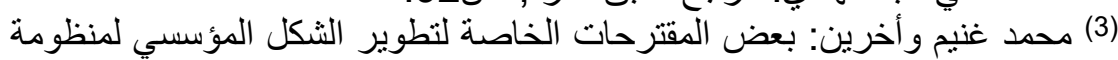

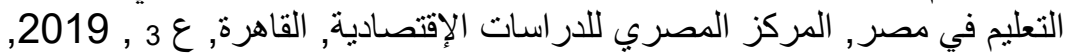

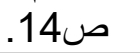




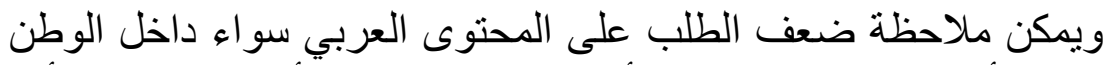

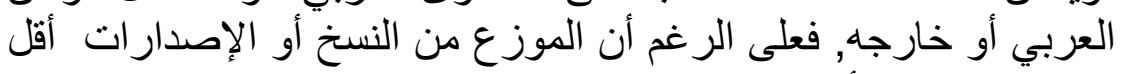

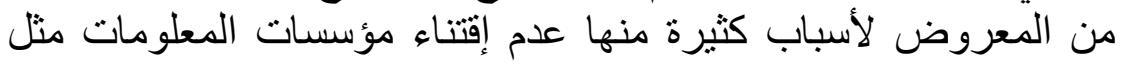

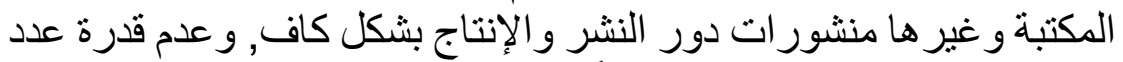

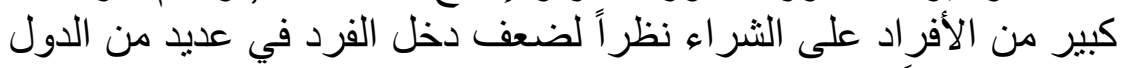

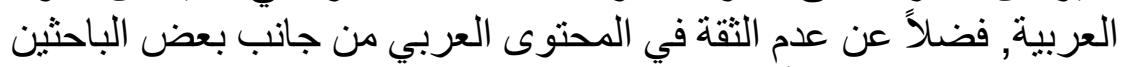

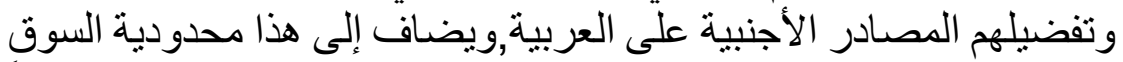

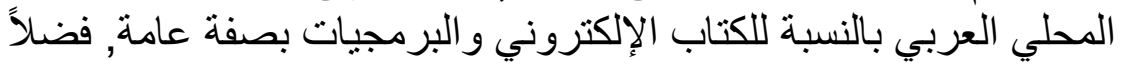
على عزوف كثير من دور النشر التجارية التقليدية في دخول سوق النئية إنتاج

ونوزيع مصادي عزور إلكترونية(2).

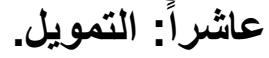

يعتمد تمويل التعليم الجامعي في مصر على التيل:

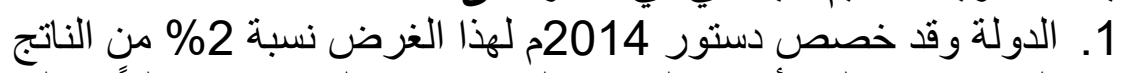

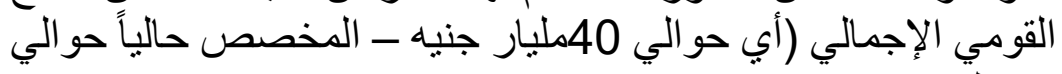
15 مليار). 2. منح البحوث العلمية من وزارة البحث العلمي/ أو الصناعة/ أوالأبحاث

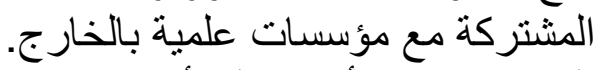

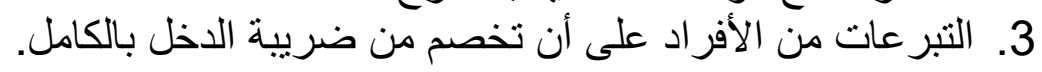

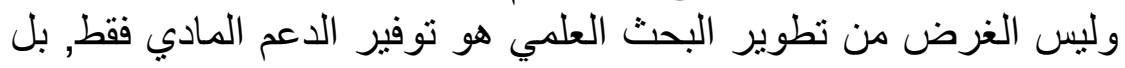

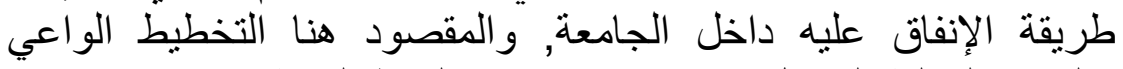
و الهادف لعملية التمويل, ويمكن ذكر بعض الإنفاق النقاط الهامة لإنه لابد مر اعاتها:

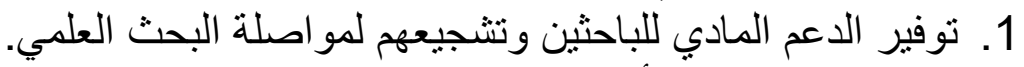

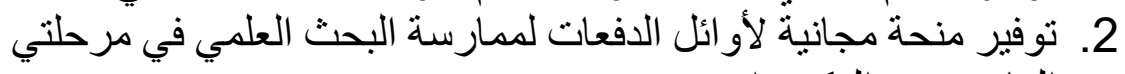
الماجستير و الدكتور اهن

3. تحسين المعامل التي تجرى فئراه فيها الأبحاث العلمية, وتزويدها بكل

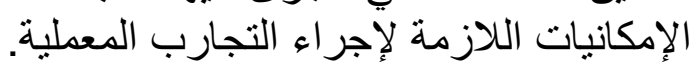
4. توفير مرتبات مجزية لأعضاء لإنجاء هيئة التدريس وخاصاً الأساتذة المتفر غين. 5. ماية حقوق الباحث العلمي ونشر أبحاثه وتسويقها. 6. تشجيع البحوث المنشورة مكافأت مالية مجزية.

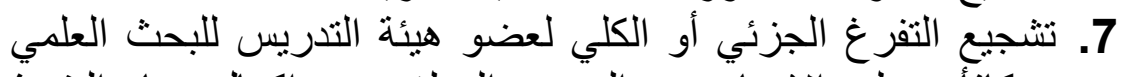

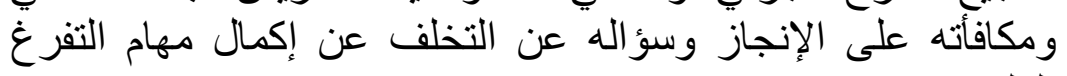
العلمي. 


\section{وقد توصلت هذه الدراسة إلى بعض النتائج.} تبين فيما سبق أن الجامعة لها دور في في البحن البحث العلمي سواء بالإيجاب أو

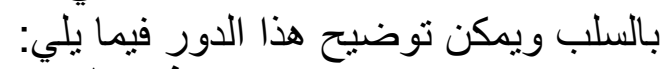
بعض الإيجابيات التي تساهم في تطوير البحن البحث العلمي:

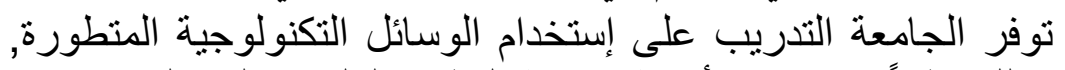

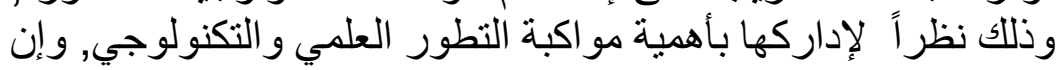

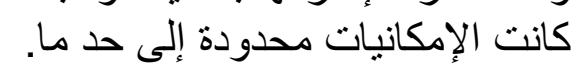
تسعى الجامعة إلى توفير الكتب المنشورة في المؤسسات البحثية

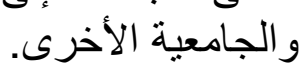

توفر الجامعة دورات في اللغة الإنجليزية واللغات الأخرى.

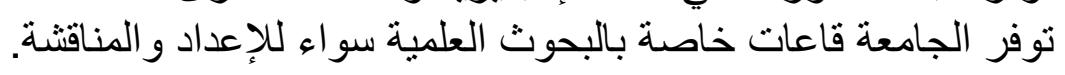

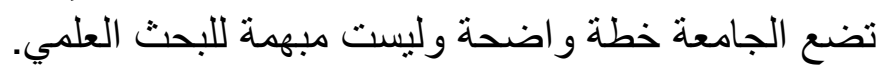

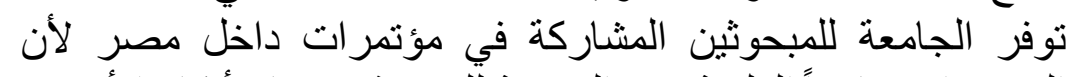

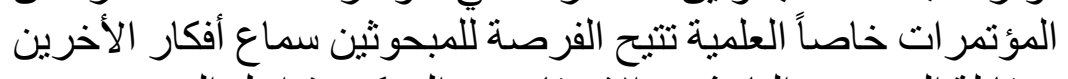

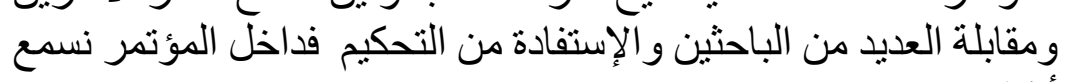

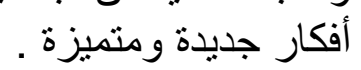

ويمكن ذكر بعض المعوقات ريمات ريما تعرقل تطوير البحث العلمي.

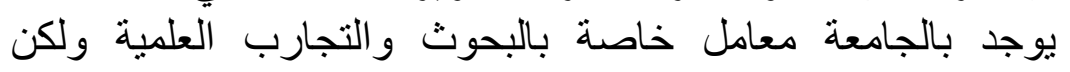

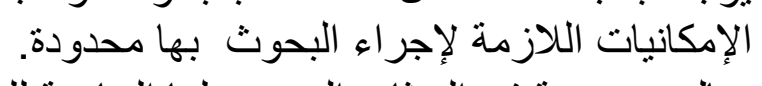

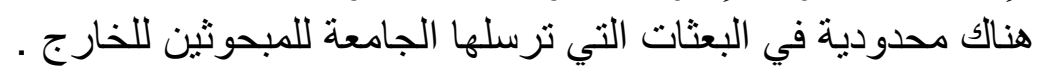

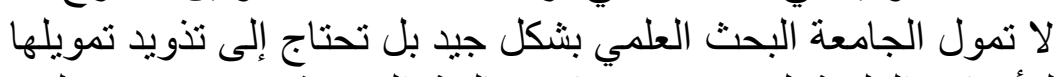

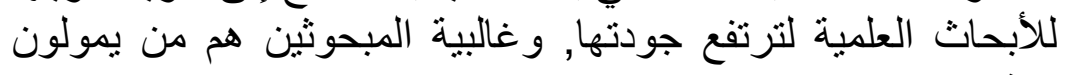
ع عدم كفاية المكافئة التي يتم الحصول عليها من الجامعة للنتاج البحثي

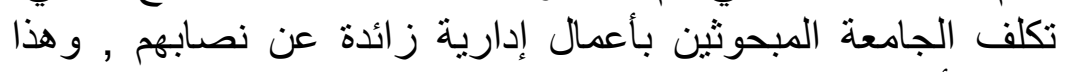

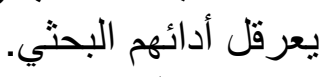

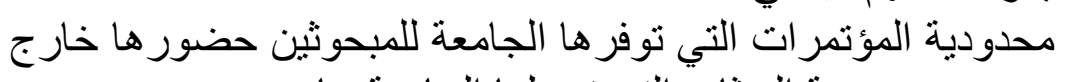

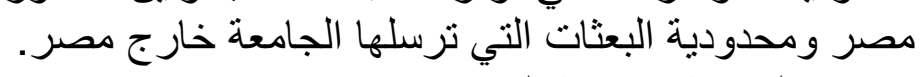

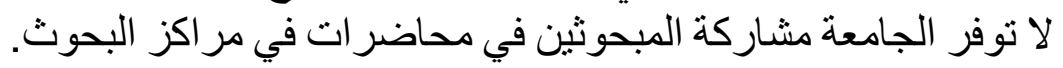

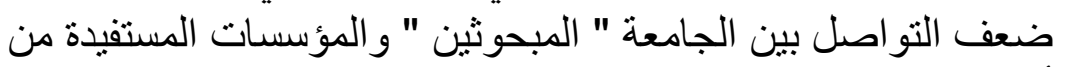

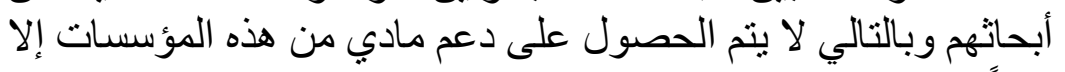
قليلاً.

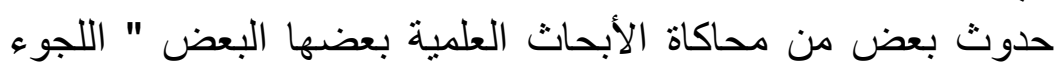
للإقتنباس و التقليد ولعل السبب في ذللك قلة التمويل ومحدودية الإمكانيات الإني 


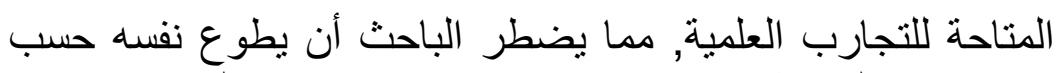

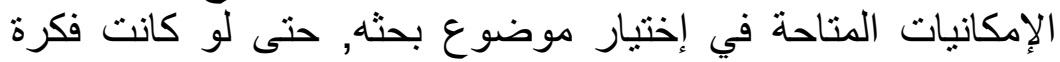
مكررة . بناء على ما تم التوصل لله من نتائج يمكن إضافة بعض التوصيات فيما يلي: نشر ثقافة البحث بين طلاب المرحلة الجامعية الأولى, وتدريبهم على البى البح

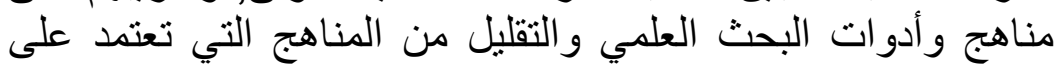
الحفظ و التلقين. تحقيق الحرية الأكاديمية قولاً وفعلاً, وتتجع الأكاديمين على إبداء

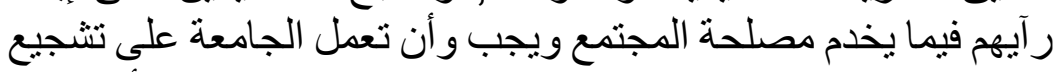

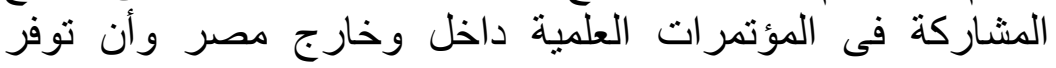

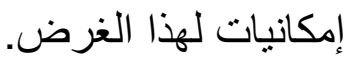

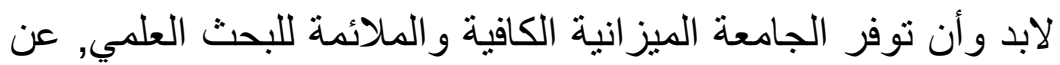

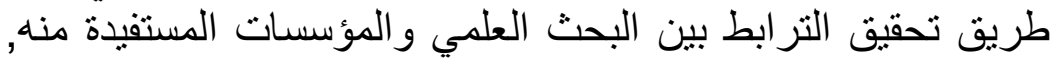

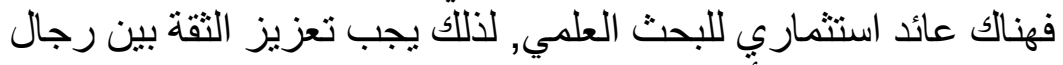

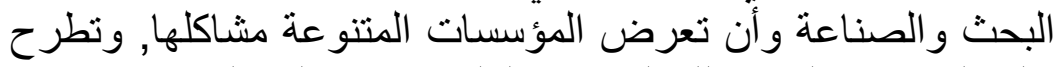

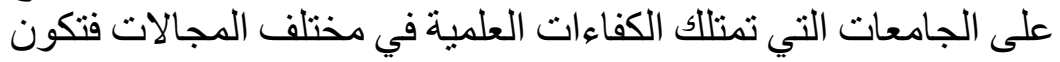
فرق بحثي قادر على حل المشكلة حيث يكون التمويل حسب مقدار التهار الإستفادة. 9 إقترن النشاط العلمي والمعرفي بإحتياجات المجتمع ومشكلاته,

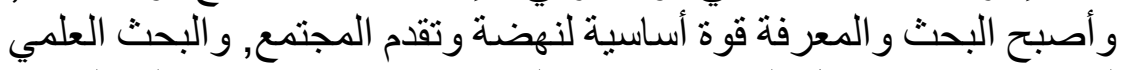

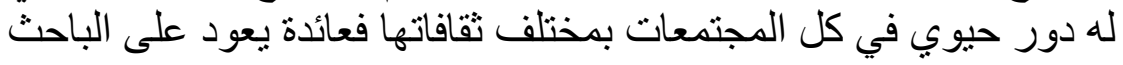

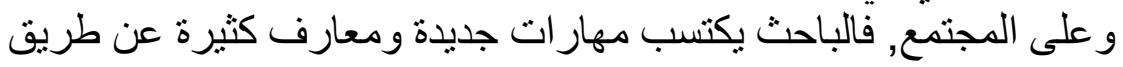

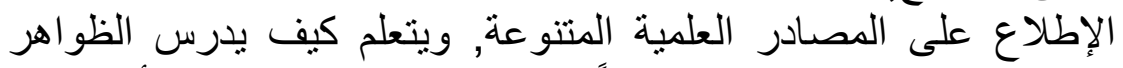

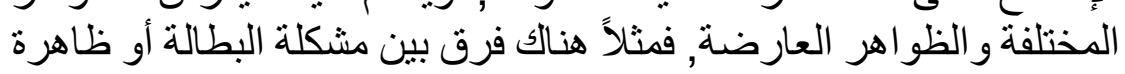

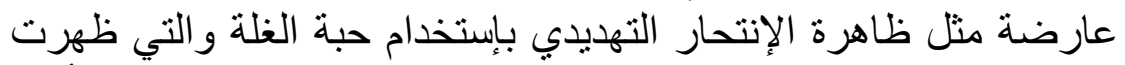

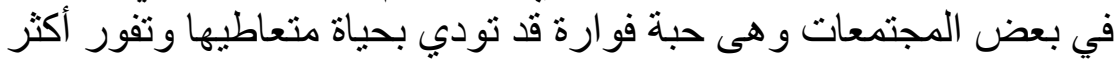

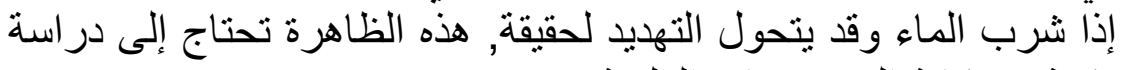
دقيقة من كافة التخصصات العلمية. ويتضح من العرض السابق أنه يقع على عاتق التهات الجامعة أهم خطوة

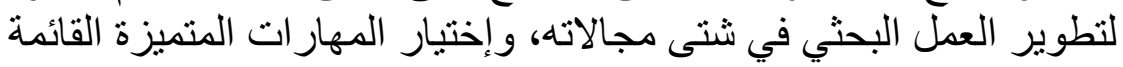

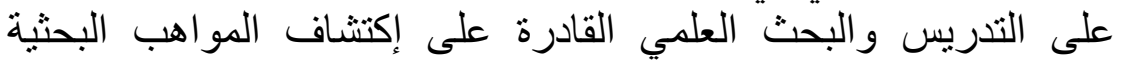
و إعدادها وتطوير ها وجعلها قادرة على الإنى الإبداع و الإبتكار . 


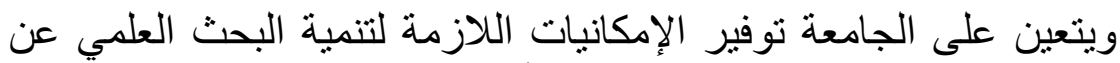

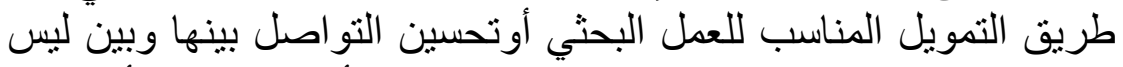

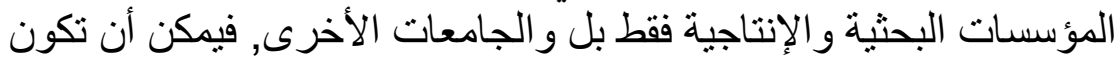

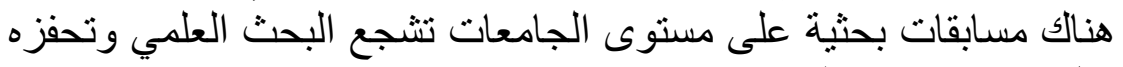
مثل مؤتمر شباب الباحثين. وتطوير المكتبة الخاصة بهاب وتئن وتوفير كل الكتب و المر اجع القيمة و الحديثة

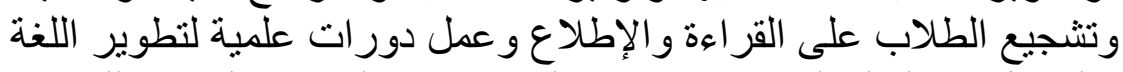

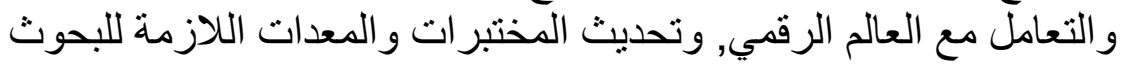

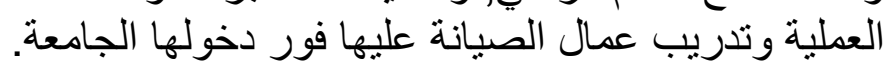

المراجع العملئ

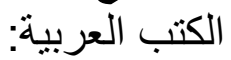

1- أحمد بدر و أخرون : المكتبات الجامعية تنظيمها و إدارتها وخدماتها

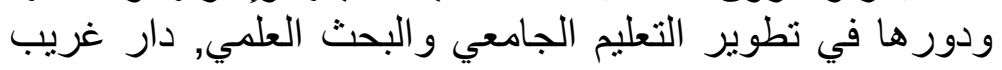

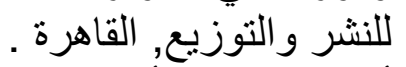
2- أحمد عزت وأخرون: الحرة الحرية الأكاديمية وإستقلال الجامعات

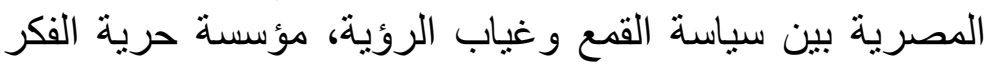

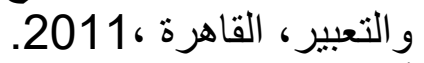
3- أمل فتحي عقل: تطوير معايير التميز في التعليم الجامعي العالي,

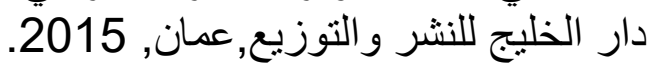

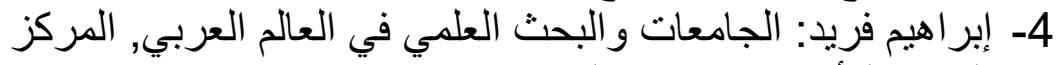

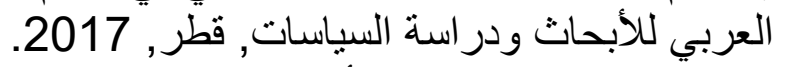

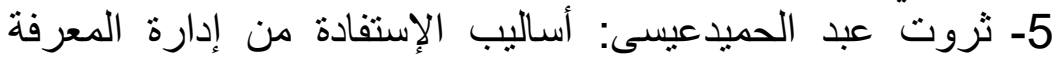

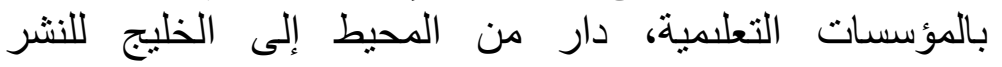
و التوزيع،عمان،

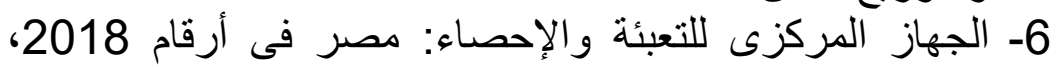

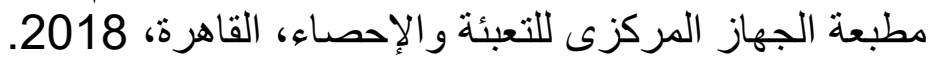

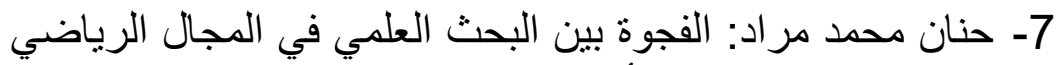

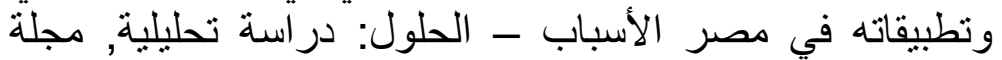
أسيوط لعالم وفنون التربية الرياضية, جامعة أسيوط, كلية التربية .2010, 8- دستور مصر 2014: جمهورية مصر العربية.

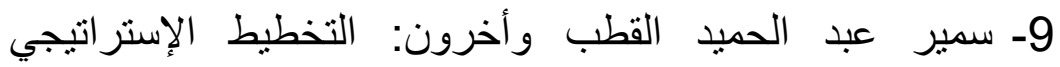

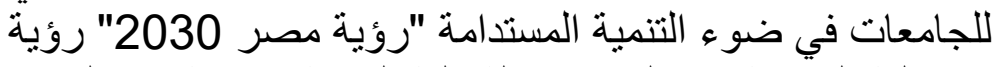
مستقبلية لجأمعة كفر الثيخ "مجلة كلية التربية, جامعة كفر الثيخ, $.14 \varepsilon$ 
10- شادية حسن فتحي: التعليم المستمر ودوره في التتمية البشرية, دار المعارف للنشر و التوزيع, الإسكندرية,

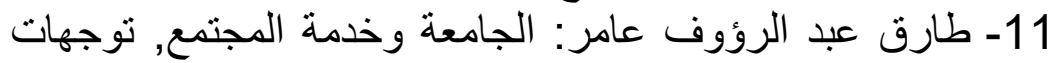

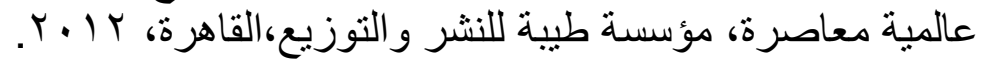
12- طه نجم: علم إجتماع المعرفة، دار الكتب الجامعية ، الإسكندرية .1996،

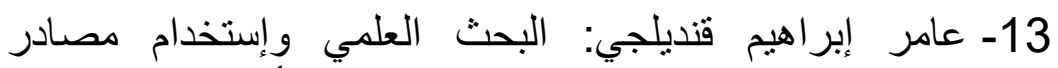

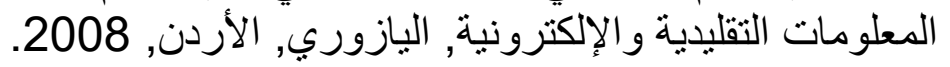

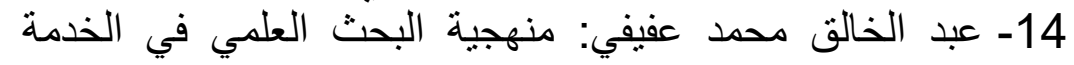

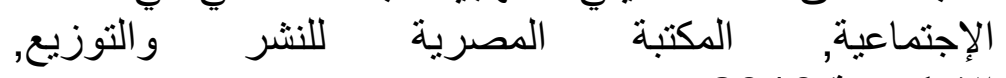
الإسكندرية,2010.

15- عبد الرحمن عامر: رأس المال المعرفي، دار الكتاب للنشر

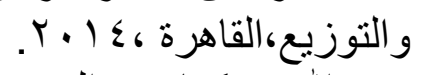

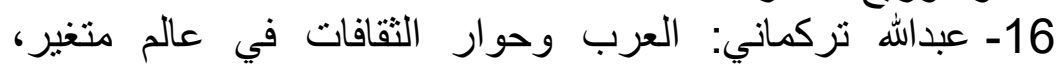

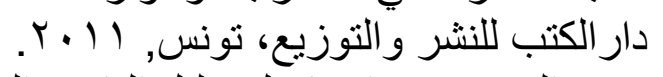
17- عبد الغني محمد إسماعيل: دليل الباحثث إلى إنى إعداد البحث العلمي,

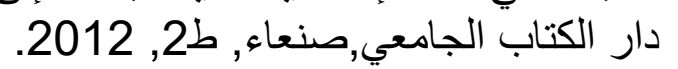
18- عدنان نايفة وآخرون: العلم والتكنولوجيا في الوطن العن العربي (الو اقع والطموح), المؤسسة العربية للنشر والثنوزيع, بيروت, النيا 2002 19- علاء الدين عبد الله: حقوق الإنسان والحريات الأكاديمية, دار غيداء, عمان, 2011.

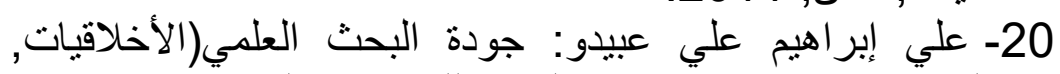
المنهجية, الإثراف), دار الوفاء للطباعة والنشر, الإسكندرية, 2014 21- غالب عبد المعطي: ثقافة البحث العلمي, دار اليازوري العلمبة,

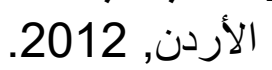
22- ماهر عبد الهادي: دور الجامعة في التتمية الإقتصادية

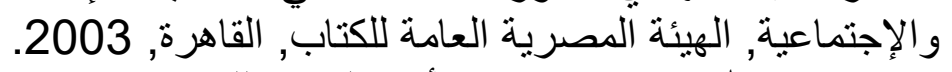

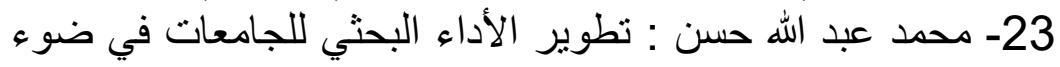

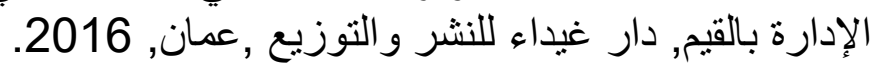

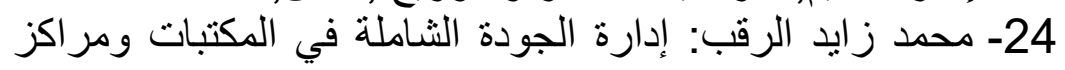

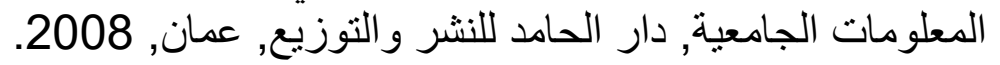

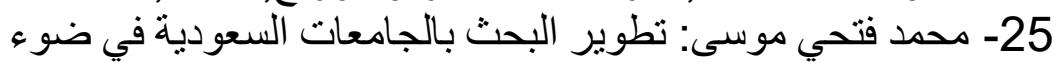

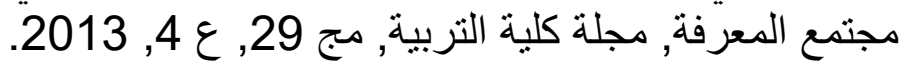


26- محمد مسعد ياقوت: أزمة البحث العلمي في الوطن العربي, دار

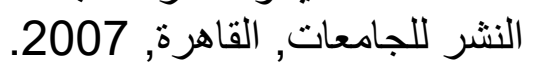

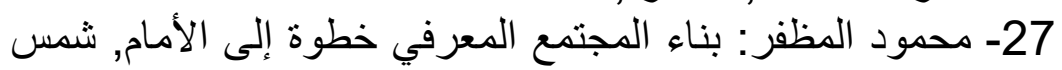
للنشر و الإعلام, القاهرة, 2020. 2027. 28- محمود كاظم التميمي: كتابة البحوث و الرسائل فئل في العلوم التربوية

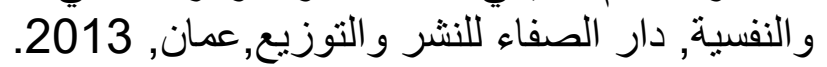

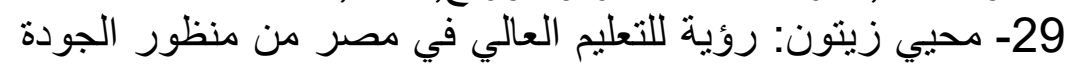

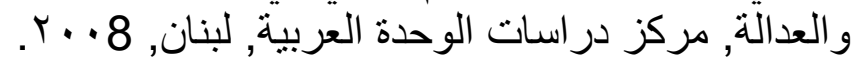

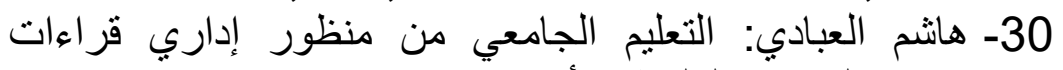
وبحوث, اليازوي العلمية, الأردن, 2011.

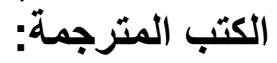

1- بيتر نايت، نرجمة خالد العامري : فن قيادة رئاسة القسم في

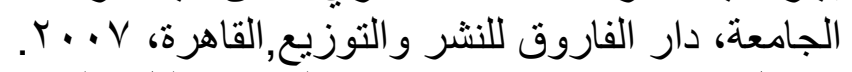

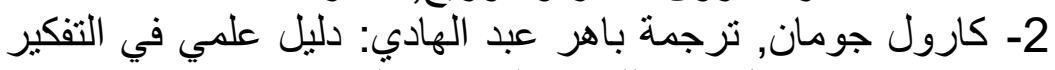

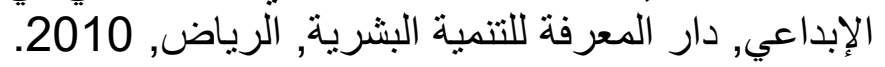

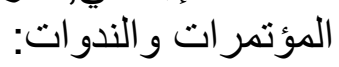

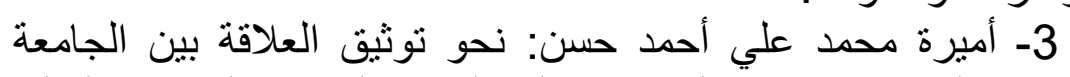
و المجتمع, جامعة البحرين- كلية التربية المؤتمر السادي/ التعلئيم العالي ومنطلبات التنمية, 2019. 2019. 4- حنان محمد مر اد: الفجوة بين البحث العلمي في المجال الرياضي

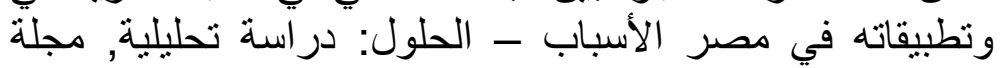
أسيوط لعالم وفنون التربية الرياضية, جامعة أسيوط, كلية التربية, 2010 5- خالد عبد الرحمن ياسين وأخرون: الكراسي العلمية ودور ها في تنمية البحث العلمي في الجامعات السعودية, المجلة التربوية, ع55

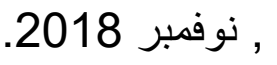
على:

https://search.mandumah.com/Record/924069 6- عدنان وديع: التعليم العالي في الوطن العربي وتحديات التقدام العلمي و التقني, شُئون عربية, جامعة الدول العين العربية - الأمانة العامة, ع ع العامي 63. 7- قطاع الثئون الاجتماعية والثقافية: وثيقة تقارير مصرية حكومية، وزارةالتخطيط، 
8- محمد نبيل نوفل: الجامعة والمجتمع في القرن الحادي و العشرين,

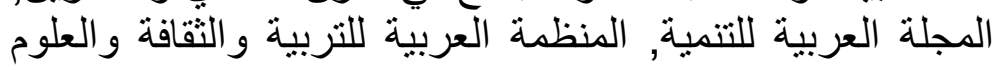

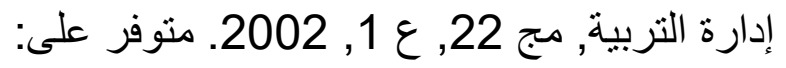
https://search.mandumah.com/Record/22341 9- محمد أحمد جرناز: البحث العلمي والرسائل الجامعية, مجلة كلية

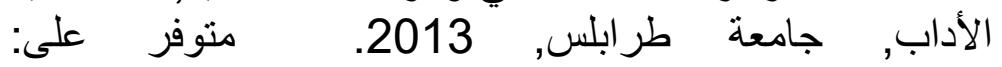
https://search.mandumah.com/record/994654 (تم الوصول في : 13-619-2019).

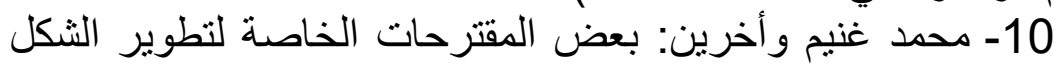

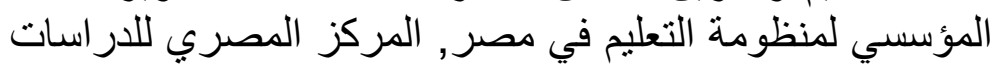
الإقتصادية, القاهرة, ع 3 , 2019.

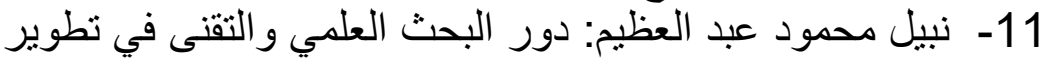

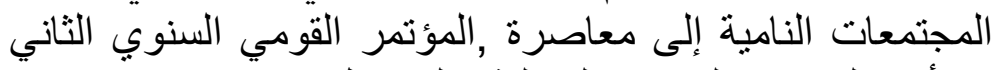

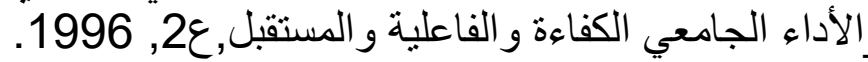
https://search,mandumah.com/Record/398184 (تم الوصول في:27-1-2021).

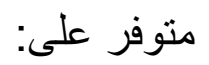

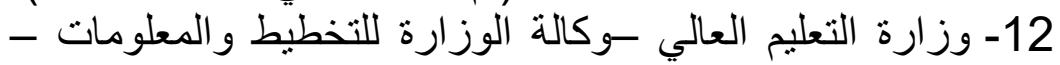

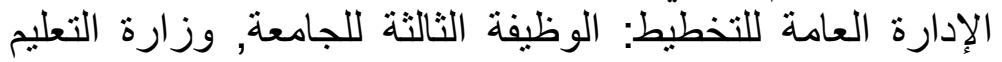
العالى_المملكة العربية السعودية, العطية العبة.2014.

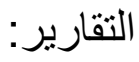

1- قطاع الثئون الاجتماعية و الثقافية: وثيقة تقارير مصرية حكومية، وزارة التخطيط,

2- وزارة التعليم العالي والبحث العلمي: إنجازات وزارة البحث

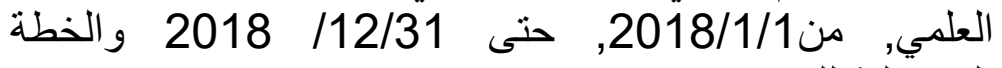
3- المستقبلية للوز ارة في 2019.

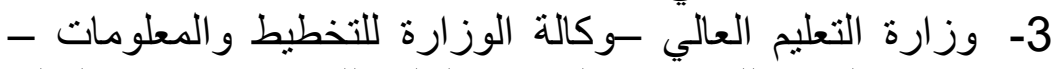

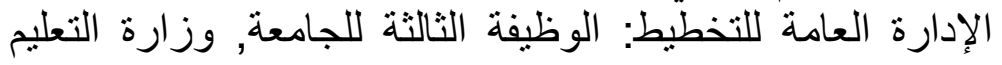

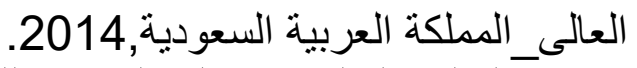

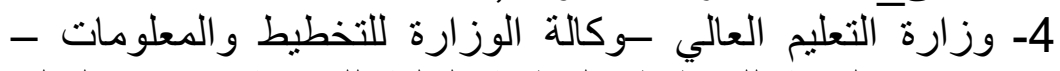

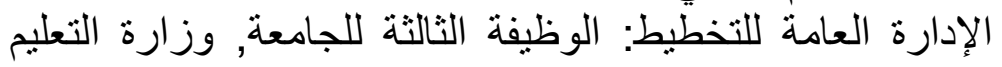

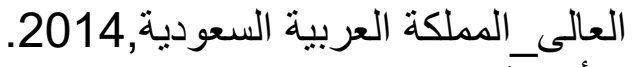

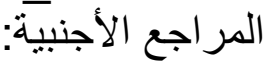


David M.Hoffman,jussi valimaa: higher education institutions in network knowledge societies, Springer,newyourk, London,2014.

Harad ,Harad, "Difficulties in Diffusion of Tacit Knowledge in Organizations" ,journal of knowledge management ,vol 12,issue ,2000. Available at: https://www.researchgate.net/publication/200773019 Difficulties_in_Diffusion_of_Tacit_Knowledge_in_O

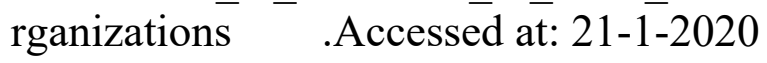

Report of a Symposium Government-University-industry: Future National Research Policies Within the Industrialized Nations, National Academy Press, Washington, D.C, 1992.

Tamas,R.Black: understanting social science research, SAGEpublication, London, 2002. 


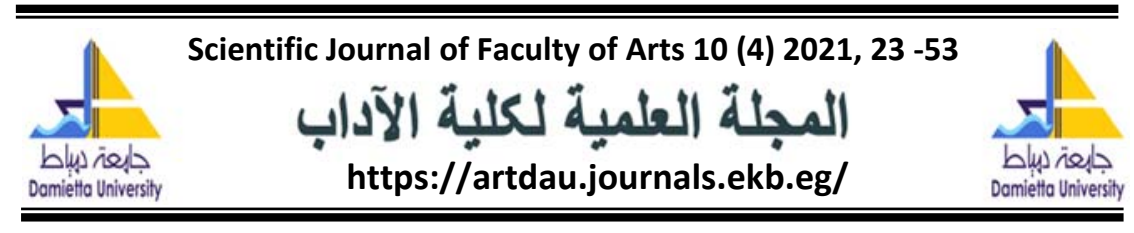

\section{The role of the university in the development of scientific research: A field study in Damietta university}

Yasmine Ibrahim Ahmed Abu Abdullah

Master's Student-Department of sociology -Faculty of Arts - Damietta University

Abstract

Scientific research has a fundamental importance is to study the phenomena of society a scientific study, and strive to achieve development and development and achieve the well-being of members of society, and the scientific research institutions have multiplied so that the university is one of the most important of these institutions has an important knowledge role which is "the transfer of knowledge through teaching, generating knowledge through research Scientific, and community development through technology transfer, innovation and community participation. There are many obstacles to scientific research, and some of these obstacles can be presented as follows: 1. Self-constraint; 2. Physical and financial constraints; 3. Administrative obstacles; 4. Political obstacles. This study is descriptive and analytical, as it relied on the descriptive analytical method and the questionnaire. The purpose of developing scientific research in universities is to achieve scientific research in the best possible way by developing every component of the scientific research system starting with developing the philosophy and goals of scientific research through acceptance of scientific

. Keywords: university, scientific research.

\section{Article history:}

Received 7 July 2021

Received in revised form 28 July 2021

Accepted 9 August 2021 